\title{
“DIVIDIR PARA IMPERAR?": UMA ETNOGRAFIA DA PRODUÇÃO DE TERRITÓRIOS INDÍGENAS NO LESTE MATO-GROSSENSE
}

\author{
"DIVIDE TO RULE?": AN \\ ETHNOGRAPHY OF THE PRODUCTION \\ OF INDIGENOUS LANDS IN EASTERN \\ MATO GROSSO.
}

\section{Luís Roberto de Paula}

luis.roberto@ufabc.edu.br

Antropólogo e Docente da Universidade Federal do ABC

Orcid: https://orcid.org/0000-0002-2278-8850

\section{RESUMO}

Expulsos de seus territórios de maneira violenta, perversa e arbitrária entre as décadas de 30 e 50 do século passado, os diversos grupos locais xavante que constituem a "Sociedade Xavante" (Maybury-Lewis,1984), passaram a retornar e recuperar esse conjunto de territórios a partir da década de 60 . Busco no decorrer deste artigo apresentar, fundamentalmente, uma das dimensões da complexa dinâmica socioespacial xavante ao dar ênfase as negociações e articulações envolvidas na produção de fronteiras territoriais numa situação etnográfica extraída de minha experiência em processos de identificação de terras. A partir desta vivência turbulenta e em um esforço retrospectivo tentei organizar o material etnográfico captado naquela situação e busquei compreender os significados embutidos no comportamento fragmentário dos grupos locais xavante diante do processo de revisão de limites de uma de suas terras indígenas. Vale dizer que os grupos locais xavante têm conseguido o reconhecimento de boa parte de suas demandas territoriais (e assistenciais) desde o início da retomada de seus direitos territoriais a partir da década de 1970. Pode-se inclusive pensar que a configuração sociológica fragmentária da "estrutura social xavante" venha ser um dos fatores sociológicos mais importantes para a sobrevivência física e cultural desse povo até o presente momento.

Palavras-chave: Terras indígenas. Conflitos fundiários. Funai. Política indigenista. Xavante.

\section{ABSTRACT}

Expelled from their territories in a violent, perverse and arbitrary way between the $30 \mathrm{~s}$ and 50s of the last century, the various local Xavante groups that constitute the "Xavante Society" (Maybury-Lewis, 1984), started to return and recover this set of territories from the 1960s onwards. In the course of this article, I seek to present, fundamentally, one of the dimensions of the complex Xavante socio-spatial dynamics by emphasizing the negotiations and articulations involved in the production of territorial boundaries in an ethnographic situation extracted from my experience in land regularization proces- 
ses. From this turbulent experience and in a retrospective effort I tried to organize the ethnographic material captured in that situation and tried to understand the meanings embedded in the fragmentary behavior of the Xavante local groups in the face of the process of reviewing the limits of one of their indigenous lands. It is worth mentioning that the local Xavante groups have been able to recognize a good part of their territorial (and assistance) demands since the beginning of the resumption of their territorial rights since the 1970s. One can even think that the fragmentary sociological configuration of " Xavante social structure" will be one of the most important sociological factors for the physical and cultural survival of these people to date.

Keywords: Lndigenous land. Land conflicts. Funai. Public politicy. Xavante.

Imaginar que uma identificação de área indígena corresponda a um simples ato técnico, como buscar antigos cemitérios ou capoeiras, algo tão fácil e direto como verificar impressões digitais, tipo físico ou amostras sanguíneas, não tem o menor fundamento. (...) Uma compreensão racional e científica dessa etapa do processo demarcatório intitulada identificação supõe, portanto, uma investigação antropológica especializada e dirigida, bem como a compreensão plena de que a proposta que dai resulta é um fenômeno político, isto é, um fenômeno que possui igualmente uma dimensão de barganha na qual os atores buscam maximizar os seus interesses face a um certo contexto histórico e uma determinada correlação de forças (OLIVEIRA FILHO; ALMEIDA, 1998, p. 76-77, grifo dos autores).

\section{APRESENTAÇÃO}

Este artigo apresenta uma síntese de investigações por mim realizadas há quase duas décadas em uma situação etnográfica bem diferente daquela que é classicamente fundamento da antropologia acadêmica: a atuação como assessor de políticas públicas voltadas para o atendimento dos direitos territoriais indígenas. Essa posição, que designo aqui como a de "antropólogo-identificador", derivou mais especificamente da minha participação em dois grupos de trabalho (GTs) autorizados pela FUNAI para a identificação e delimitação de quatro áreas contíguas à Terra Indígena Parabubure (MT) reivindicadas como "terras tradicionalmente ocupadas" por conjuntos de grupos locais Xavante ali residentes ${ }^{1}$.

A "missão" atribuída ao antropólogo num trabalho com esse perfil é a de produzir dados etnográficos baseados em fontes orais e documentais visando subsidiar a elaboração de uma peça jurídica, o relatório circunstanciado de identificação e delimitação (RCID), que busca demonstrar a legalidade e a legitimidade das demandas territoriais da população indígena em questão. A elaboração do RCID está vinculada a parâmetros normativos expostos em diplomas específicos sobre a matéria ${ }^{2}$.

É a partir de uma reflexão retrospectiva sobre essa experiência de regularização fundiária que se delineia o objetivo central deste artigo: apresentar uma "descrição densa" do complexo e contraditório processo de produção de fronteiras territoriais indígenas levado a cabo por lideranças Xavante durante $\mathrm{o}$ andamento dos grupos de trabalho. A produção dessas fronteiras indígenas encontra-se associada diretamente a (in)tensas dinâmicas de negociação e articulação operacionalizadas entre as próprias lideranças indígenas, como também destas com outros atores não-indígenas envolvidos nessa arena de disputas territoriais ${ }^{3}$. 
É importante destacar que a situação etnográfica foco do artigo encontra-se, também conectada a antigas situações históricas que constituem etapas de uma longa trajetória de contato interétnico na qual grupos locais Xavante foram, simultaneamente, subordinados e protagonistas em inúmeros e distintos processos de desterritorialização e reterritorialização (HAESBAERT, 2004) ocorridos no leste mato-grossense desde o século XIX.

Trata-se de uma tentativa de síntese etnográfica de um período histórico recortado metodologicamente a partir da noção de situação histórica de Oliveira (1988). O aspecto metodológico fundamental dessa noção que me interessa mais de perto aqui destacar é aquele que define que os eventos investigados:

(...) devem ser interpretados por meio de conceitos já anteriormente definidos, que permitem aprender as finalidades perseguidas pelos diferentes atores, considerando o conjunto de alternativas subjacentes, explicitando as opções e as táticas de ação utilizadas e tentando dessa forma encontrar uma conexão lógica entre a sucessão de eventos descritos (OLIVEIRA, 1988, p. 170).

Essa assertiva é o fundamento da seleção que fiz de um conjunto de eventos compreendido em termos cronológicos a partir de 1985, com as notícias das primeiras reivindicações pela revisão dos limites da Terra Indígena (T.I.) Parabubure, e terminado em 2005, com a entrega dos relatórios de identificação e delimitação das últimas dessas demandas por terras à Fundação Nacional do Índio (FUNAI).

Vale mencionar que há um extenso e consolidado debate teórico e metodológico sobre as noções (e distinções) entre "terras", "territórios" e "territorialidades" indígenas na etnologia nacional ${ }^{4}$. É possível destacar que, no caso específico das populações indígenas situadas no Brasil, essas distinções têm sido caracterizadas, desde o final da década de 1970, pela oposição conceitual entre a noção de "terra indígena" - produto jurídico-administrativo do Estado nacional - e as de "territórios" e "territorialidades" indígenas, expressão de lógicas espaciais nativas específicas e, portanto, irredutíveis à lógica socioespacial-administrativa mais ampla do Estado nacional. Em poucas palavras, as "terras indígenas" seriam produtos históricos dos "encapsulamentos" político-administrativos aos quais as multifacetadas e dinâmicas "territorialidades indígenas" teriam sido submetidas no decorrer de séculos de expropriação fundiária. (SEEGER; VIVEIROS DE CASTRO, 1979; OLIVEIRA,1998; HAVT, 1999, 2001; LADEIRA, 2001; LITTLE, 2002; GALLOIS, 1996, 2004).

Por último e não menos importante, diante da situação etnográfica que será aqui apresentada não há como não lembrar da famosa fórmula do "dividir para conquistar", base do exercício da supremacia de países colonizadores sobre os colonizados (e, de maneira simétrica, de estados nacionais colonizadores sobre suas minorias étnicas, o que remete aos clássicos debates sobre "situação colonial" (Balandier,1993[1954]) e "colonialismo interno" (Stavenhagen,1963). Sem ignorar que a dominação concreta continua a ser um dos ingredientes mais potentes presente na relação entre estados nacionais e minoria étnicas, espero poder demonstrar para além dessa dimensão mais visível do processo, a também coexistência do protagonismo dos grupos locais Xavante na produção das fronteiras territoriais indígenas. Por isso a interrogação presente no título é propositalmente provocadora.

A polarização colonizador/colonizado desaparece e surgem outras polarizações. Assim, temos de buscar talvez uma maior precisão conceitual. Partindo do conceito de situação colonial, tal como formulado por 
Georges Balandier, e de descolonização, proposto por Fanon e como acima apresentamos, podemos ver que, em realidade, existem formas diversificadas para além da situação colonial e "pós-colonial" e essas formas complexas continuam sendo exteriores e interiores ao próprio Estado nacional. A condição pós-colonial tem de ser caracterizada, a questão é quais conceitos podem ser acionados para isso. Múltiplas situações coloniais, múltiplas vias de descolonização, múltiplas condições pós-coloniais. Estamos muito longe da homogeneidade que a ideia de colonialidade parece sugerir (FERREIRA, 2014:278).

Apresentados e discutidos em linhas gerais os objetivos teóricos e metodológicos que estimularam a elaboração deste artigo, passemos então à apresentação e análise dos elementos sociológicos e políticos presentes nas situações históricas articuladas ao processo de produção de fronteiras territoriais indígenas no leste mato-grossense.

\section{A SITUAÇÃO ETNOGRÁFICA COMO PARTE DE UMA SITUAÇÃO HISTÓRICA MAIS AMPLA (1985-2005)}

Entre 1985 e 2005 foram muitos os pedidos de revisão dos limites jurídicos-territoriais endereçados à FUNAI, por diversos grupos locais Xavante residentes na maioria das suas nove terras indígenas atuais. Em vários desses casos, a FUNAI autorizou distintos grupos de trabalho a realizar os trabalhos de identificação de áreas reivindicadas como terra de ocupação tradicional e, dentre elas, inclui-se a Terra Indígena Parabubure, localizada entre os rios Rio Kuluene e Couto Magalhães, formadores do Rio Xingu ${ }^{5}$, referência da situação etnográfica focalizada nesse artigo.

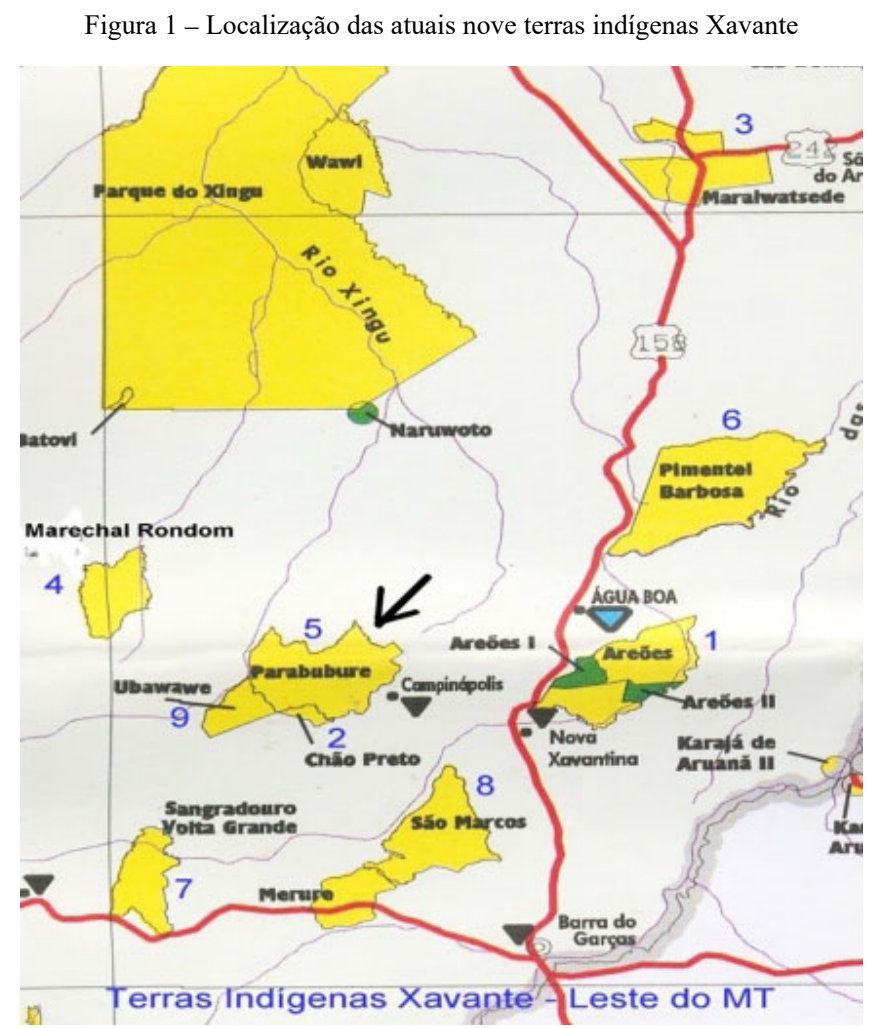

Fonte: De Paula, 2007. 
Entretanto, somente em março de $1996^{6}$ a Presidência da FUNAI autorizaria a ida a campo do primeiro grupo de trabalho (GTs) para identificação de cinco áreas indígenas (I, II, III, IV e V) contíguas, portanto, a Terra Indígena Parabubure ${ }^{7}$.

Um parêntese se faz aqui necessário para que o leitor possa acompanhar com mais facilidade a descrição etnográfica que se segue. Esse conturbado, complexo e não finalizado até os dias de hoje processo de revisão de limites da T.I. Parabubure contou com a aprovação legal e operacionalização em campo de cinco grupos de identificação entre os anos de 1996 e 2003. Assim, como dito acima, o GT inicial teve andamento em 1996. Um segundo e terceiros iriam a campo em 1998. Um terceiro em 2000 e um quarto e último em 2003. Doravante, cada um desses GT será denominado respectivamente da seguinte maneira: GT-1996; GT-1998(A); GT-1998(B); GT-2000 e GT2003.

O primeiro relatório circunstanciado de identificação (RCDI) entregue a FUNAI pelo primeiro GT, portanto, o GT-1996, baseava-se fundamentalmente na apresentação da organização social Xavante e na sua história de contato com segmentos da sociedade nacional. Toda a ênfase argumentativa para legitimar as fronteiras territoriais demandadas pelos grupos locais Xavante recaía sobre o processo histórico de expropriação do que teria sido no passado o território tradicional Xavante.

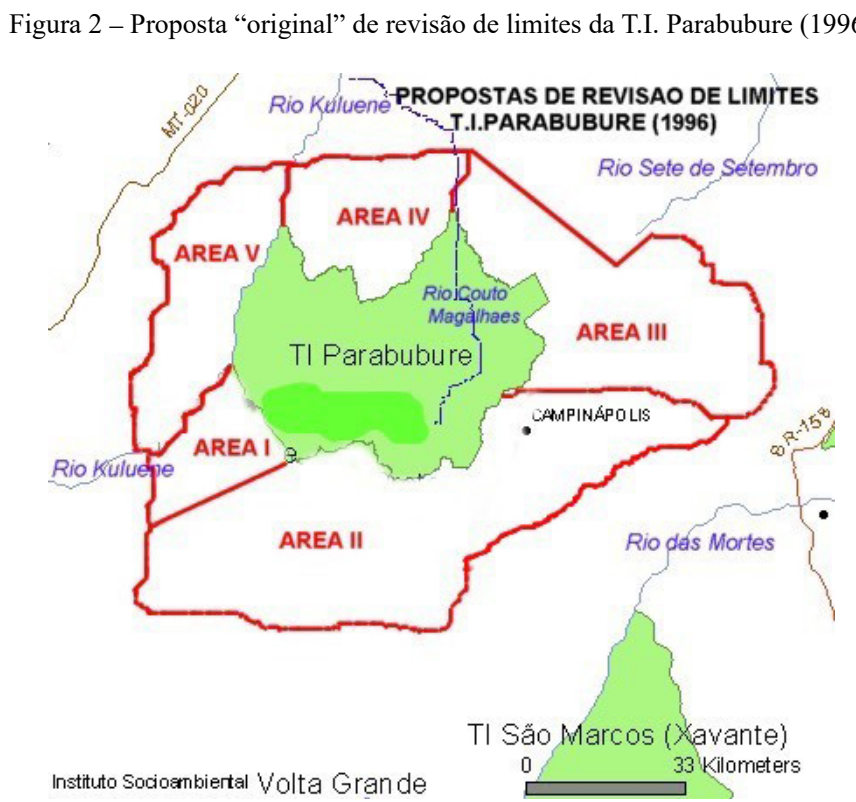

Fonte: De Paula, 2007.

A FUNAI optaria por não aprovar a revisão de limites territoriais proposta em sua integralidade (portanto a totalidade das cinco áreas reivindicadas) e a alegação central para tanto era a de que o relatório não oferecia elementos técnicos suficientes para caracterizar o conjunto das cinco áreas como "terras tradicionalmente ocupadas" pelos Xavantes a partir de seus "usos, costumes e tradições" ou como portadoras de recursos ambientais imprescindíveis a reprodução física e cultural do grupo (conforme previsto no artigo 231 da Constituição Federal de 1988).

Apesar de avaliado, portanto, como inadequado no que diz respeito a critérios técnicos e jurídicos pelo próprio órgão indigenista, o GT-1996 e seu primeiro relatório circunstanciado sobre a revisão de limites da T.I. Parabubure implicaria em duas consequências práticas: primeiro, como apresentado acima, traria um mapa com a indicação geoespacializada das cinco áreas contíguas a 
T.I. Parabubure reivindicadas por distintos grupos locais Xavante; segundo, e de maneira surpreendente, na aprovação pela Funai - a mesma que negara a aprovação da proposta de revisão integral das cinco áreas — da identificação e delimitação somente da Área I (que passaria então a ser denominada T.I. Ubawawe). Isso daria início a uma aparente estratégia levada a cabo pelo órgão indigenista em atender de maneira parcial as reivindicações territoriais dos grupos locais Xavante de Parabubure. Voltarei a isso.

Os motivos principais do GT-1996 não apresentar o relatório de identificação das cinco áreas de maneira completa — ou seja, atender os critérios exigidos pelos diplomas que orientam este tipo de processo de regularização fundiária - dizem respeito diretamente à pressão política regional e local anti-indígena. Tal pressão pode ser melhor compreendida a partir de pelo menos três dimensões: a) pela visibilidade pública dada aos procedimentos de regularização fundiária pelas mídias regionais, que acabam por insuflar os ânimos de autoridades e da população local não-indígena; b) pelo impedimento dos GTs entrarem nas áreas reivindicadas (compostas por grandes fazendas, assentamentos rurais, pequenas propriedades etc.) por parte de fazendeiros ou outros segmentos locais; c) pelas (des)articulações dos setores administrativos do próprio órgão indigenista antes, durante ou depois do funcionamento do GT em campo (seja nas esfera da administração regional — que deveria dar apoio às equipes técnicas em campo - ou mesmo na própria sede do órgão em Brasília). Essas três dimensões nas quais se manifestam de maneira mais direta ou indireta as pressões políticas anti-indígenas se repetirão, como será visto, no andamento e operacionalização dos futuros que GTs que voltarão a campo anos depois para tentar finalizar o processo de identificação das outras quatro áreas reivindicadas pelos Xavante de Parabubure.

Apresento a seguir alguns aspectos relacionados à primeira dimensão na qual as pressões políticas contrárias aos trabalhos do GTs se manifestam com bastante intensidade, ou seja, a visibilidade pública dada pela mídia regional ao processo de regularização fundiária indígena em foco. As outras duas dimensões aparecerão no decorrer das demais seções que compõem o artigo.

De maneira parcial e enviesada, esse papel da mídia regional em dar visibilidade pública à chegada e operacionalização dos GTs de identificação será não só constante, como se intensificará diante de futuras tentativas de operacionalização dos outros grupos de trabalho. Ressalte-se que a influência "tóxica" da mídia regional e local na ampliação dos conflitos territoriais indígenas é matéria ainda a ser aprofundada em pesquisas não só entre os Xavantes, como também em outras tantas arenas de contato interétnico conflituosas espalhada pelo país.

Vejamos um exemplo que ilustra esse papel ativo da mídia ocorrido ainda durante a ida a campo do primeiro GT para em 1996:

Um novo conflito entre Xavantes e brancos poderá eclodir a qualquer momento na região do Médio Araguaia, nos municípios de Campinápolis, Água Boa, Novo São Joaquim e Paranatinga devido à possibilidade de criação de uma nova reserva indígena na região (DIÁRIO DE CUIABÁ, 22 out. 1996).

Passados quase quatro anos, em setembro de 2000, um novo grupo de trabalho seria autorizado pela FUNAI para identificação e delimitação das áreas reivindicadas pelos Xavante de Parabubure. Entretanto, em uma inovação administrativa da FUNAI, o processo integral de revisão de limites das quatro áreas reivindicadas não ocorreria naquele momento, sendo autorizada apenas a revisão dos limites das áreas IV e V (GT-2000). As áreas II e III só viriam a ser objeto de nova identificação em 2003. Por estratégia de apresentação desse 
artigo, descreverei aspectos essenciais dessas novas tentativas de identificação e delimitação das quatro áreas mais à frente.

Por ora, atenho-me aqui no papel desempenhado pela mídia regional.

De maneira estruturalmente idêntica ao que ocorrera na operacionalização do GT-1996, a mídia regional acionaria novamente uma série de ataques publicitários ao processo de regularização fundiária de Parabubure. É assim que, três meses após a entrega oficial do relatório de identificação e delimitação das Áreas IV e V (elaborado pelo GT-2000), o encarte de uma revista de divulgação regional intitulada "Produtor Rural" apresentava uma capa e um extenso artigo em que identificava e analisava os "interesses" que estariam "por detrás" da "ampliação e criação de novas reservas indígenas no Mato Grosso". A capa fala por si só. Junto à matéria encontramos um mapa dos então já conhecidos e bastante famosos (pelo menos, regionalmente) limites das áreas II, III, IV e V. Ressalte-se que os contornos das Áreas II e III ainda têm como referência a proposta originalmente entregue pelo primeiro GT- 1996.

Figura 3 - "Onde a Funai quer chegar?"

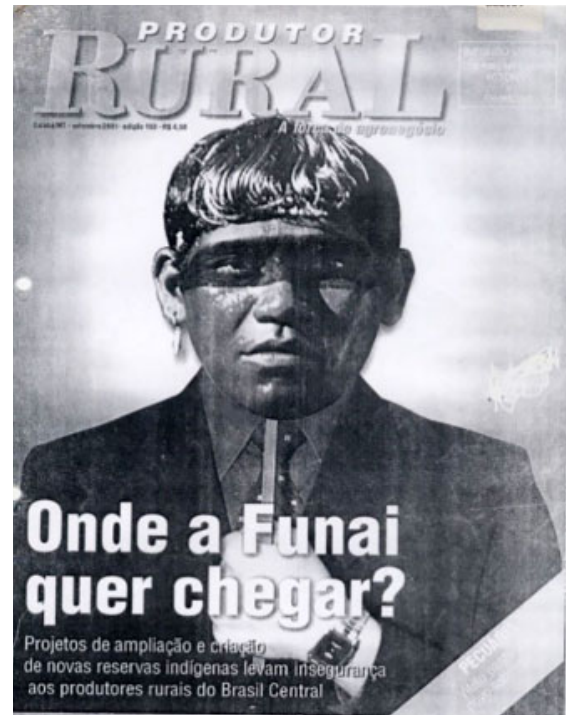

Fonte: De Paula, 2007.

Figura 4 - Proposta de revisão (1996)

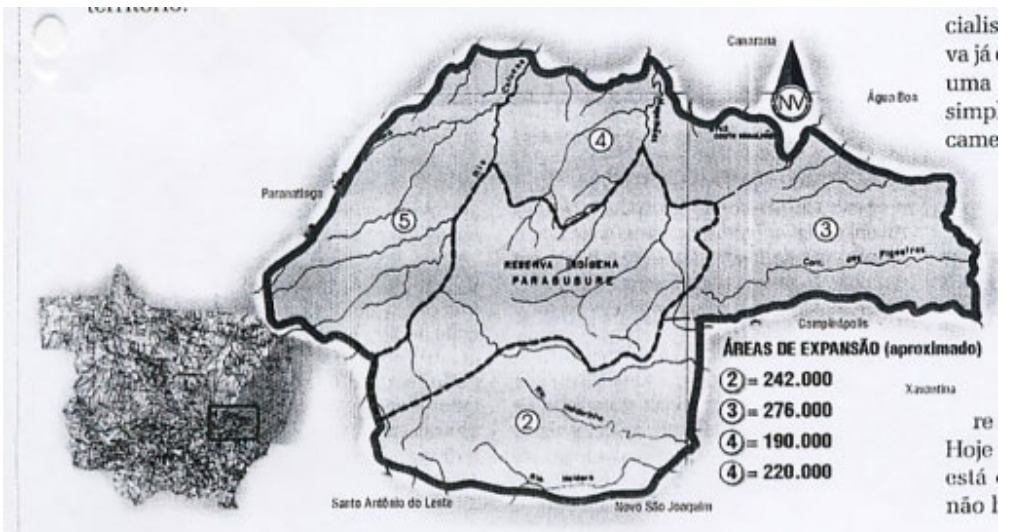

Fonte: De Paula, 2007.

Outra peça midiática produzida na mesma época (2001-2003) explicita a articulação existente entre diversos atores regionais contra os processos de 
revisão de limites das terras indígenas Xavante. Com o título sensacionalista "Facada no Coração" e um subtítulo mais desarrazoado ainda, "ONGs e FUNAI solapam Mato Grosso, Tocantins, Pará e Amapá para criar uma Nação Indígena independente na Amazônia", o suplemento do Jornal do Estado (MT) "Revista Virou Manchete", de agosto de 2003, enumera uma série de argumentos para provar que estaria em curso uma grande conspiração internacional para “esfacelar considerável fatia territorial da Amazônia” através da criação de um “estado indígena” — "a Grande Nação Xavante".

Figura 5 - "Facada no Coração"

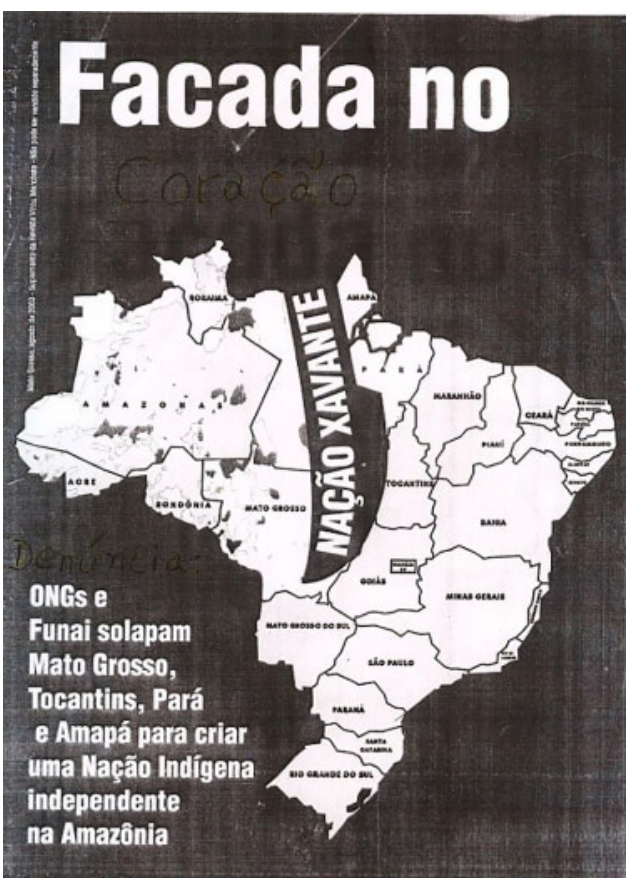

Fonte: De Paula, 2007.

Visando legitimar sua tese, a revista abre espaço para falas contundentes de "autoridades" políticas regionais, de jornalistas com certa erudição, de pequenos agricultores e comerciantes e, estrategicamente, de alguns Xavantes cooptados no complexo e contraditório processo de dividir para imperar em curso naquela região.

Essas estratégias terão profundas implicações na condução administrativa e política do processo de identificação tanto das quatro áreas. Mais do que isso, tais estratégias de pressão local e regional serão responsáveis diretas por pedidos momentâneos de "desistência" do andamento do processo de revisão de limites que passariam a chegar à FUNAI nesse período endereçados por algumas das lideranças Xavante mais comprometidas com a luta pela recuperação territorial.

Além dos pedidos de suspensão da proposta de revisão de limites de algumas das áreas reivindicadas, outro efeito será percebido na continuidade desse processo: lideranças Xavante pediam a retomada dos processos de identificação, mas com novas propostas de contornos territoriais, em sua maioria, menores quando comparados àqueles propostos pelo primeiro GT que foi a campo em 1996. Entretanto, os novos grupos de trabalho que seriam responsáveis por reconfigurar os limites territoriais das quatro áreas contiguas a T.I. Parabubure entre 2000 e 2003, incorporariam fortemente um dos aspectos centrais que orientam o processo de identificação de terras previsto no artigo 231: a indicação das áreas "imprescindíveis à preservação dos recursos ambientais 
necessários ao bem-estar" do grupo indígena. Note-se, portanto, a contradição latente que passaria a existir na condução dos grupos de trabalho: de um lado, grupos locais Xavante que pressionados por forças políticas anti-indígenas, admitiriam suspender ou mesmo reduzir os limites pretendidos originalmente e, de outro, o novos grupos de trabalho que seguindo orientações normativas da FUNAI, recomendariam a ampliação dos mesmos limites!

Interessante notar que, na tentativa de levar a sério os princípios constitucionais que orientam o processo de identificação de terras, os grupos de trabalhos contaram com uma oposição ferrenha não só por parte dos segmentos regionais de praxe (fazendeiros, prefeitos, mídia etc.), como também, de maneira surpreendente, por parte de alguns dos técnicos que compunham o próprio grupo, vinculados aos órgãos fundiários e ambientais regionais. Esses membros do grupo de trabalho não faziam a menor questão de que os trabalhos de identificação alcançassem seus objetivos. No decorrer da convivência de campo, mais do que a "insegurança" que está presente todo tempo nesse tipo de trabalho, os motivos da resistência por parte de alguns técnicos se revelaram associados à visão de que as demandas territoriais dos índios eram, no mínimo, inadequadas. Assim, se o bordão "muita terra para pouco índio" era facilmente identificado nas narrativas de vários atores não-indígenas regionais, dentro do grupo de trabalho a mesma representação distorcida aparecia não só nos discursos de técnicos de outros órgãos envolvidos com a questão fundiária regional, como também, e de maneira a causar certa perplexidade, em questionamentos pontuais de alguns funcionários regionais da própria FUNAI, que costumam dar suporte a esse tipo de trabalho. A nítida percepção é a de que o antropólogo e o ambientalista ficavam cada vez mais isolados dentro do grupo de trabalho quanto mais expressam suas convicções de ordem técnica sobre a legitimidade das reivindicações territoriais indígenas. Essas perspectivas contraditórias entre membros do GT, que vão se apresentando (e sendo apreendidas) no decorrer do trabalho em campo, também acabam produzindo efeitos práticos no andamento do processo de identificação territorial (desde o atraso na entrega de relatórios ao antropólogo-coordenador para elaboração do relatório final de identificação, passando por alguns entregues com baixa qualidade, até chegar àqueles nunca entregues). Vale salientar que todos esses relatórios são peças imprescindíveis ao encaminhamento adequado dos processos demarcatórios integrais, já que têm como foco os diagnósticos ambientais, de ocupação agropecuária regional, de perfil fundiário dos estabelecimentos e ocupantes presentes nas áreas reivindicadas, dentre outras dimensões.

Um dos últimos momentos reveladores do clima de tensão e tentativas de controle do processo demarcatório por parte de atores não-indígenas ocorreu por conta da própria iniciativa de componentes do GT-2000. Em uma determinada ocasião, a equipe foi "convidada" a participar de uma reunião com os fazendeiros da região no intuito de prestar esclarecimentos sobre o trabalho e o processo de identificação e delimitação em curso. Foi consensual que deveríamos aceitar o convite na busca de serenar os ânimos que, àquela altura, já estavam bastante acirrados. $\mathrm{O}$ recado dos fazendeiros foi bastante claro: queriam um "acerto justo", quer dizer, uma indenização que compensasse os investimentos que eles fizeram em suas respectivas fazendas (inclusive, aventaram a hipótese de a indenização pela terra ser paga com TDAs ${ }^{8}$ ); não queriam "terra em outro lugar" como forma de compensação, o que era um mecanismo muito utilizado na década de 1970 nessa região; e firmaram posição de que para efetuar o levantamento fundiário - uma das etapas que compõem o processo demarcatório após a conclusão da etapa de identificação —, seria necessária a emissão de mandado judicial e a presença da Polícia Federal para garantir, segundo os diplomáticos interlocutores, "a segurança dos técnicos" que por lá se aventurassem. Foi bastante difícil fazê-los compreender que uma terra, quando 
é declarada de posse indígena, não está sujeita a qualquer tipo de indenização - a não ser o pagamento das benfeitorias nelas realizadas —, o que, inclusive, serviu para exaltar mais os ânimos de nossos interlocutores. Segundo um dos fazendeiros, um dos aspectos envolvidos nessa situação conflituosa pode ser assim resumido: a maioria dos fazendeiros, diferentemente dos índios, "não têm raiz" nenhuma no lugar - o que, aliás, só reforça a imagem que os Xavante a eles atribuem. Portanto, é só a "FUNAI" pagar um "preço justo" que eles vão embora satisfeitos, principalmente porque não "aguentam" mais ser "vizinhos de índio". Interessante notar que, questionado sobre a possibilidade de um dia haver uma convivência tolerante entre índios e não-índios, um dos fazendeiros respondeu que isso seria impossível de acontecer, pois trata-se de uma "guerra" que nem aquela travada entre "judeus e palestinos".

\section{“DIVIDIR PARA IMPERAR"? (1998-2000)}

Como apresentado da seção anterior, muitas especulações veiculadas pela mídia regional sobre a primeira proposta oficial dos contornos territoriais dos limites das cinco áreas reivindicadas pelo Xavante de Parabubure, produzidas pelo GT-1996, dariam margem ao adiamento do processo de regularização fundiária que só seria retomado em sua totalidade (ou seja, envolvendo quatro áreas restantes) a partir de 2000.

Entretanto, como já adiantado, entre 1996 e 2000, duas medidas político-administrativas da FUNAI antecipariam o processo de regularização fundiária que envolvia a totalidade das cinco áreas reivindicas pelos grupos locais Xavante de Parabubure. Assim, em1998, o órgão indigenista autorizou a formação de um segundo GT (GT-1998A) para atender o pleito de apenas um dos grupos locais de Parabubure, redundando na identificação da denominada Área I.

O mais curioso nessa antecipação é que, em menos de dois anos, a Área I - a partir de então, T.I. Ubawawe - passaria de maneira brevíssima por todo um longo e demorado trâmite burocrático que é exigido no processo de regularização fundiária envolvendo terras indígenas: identificação e delimitação; período de contraditório; levantamento fundiário (e desintrusão de não-índios com o pagamento das benfeitorias); demarcação física; homologação e registro em cartório.

Figura 6 - Demarcação das T.I.s Ubawawe e Chão Preto (1998)

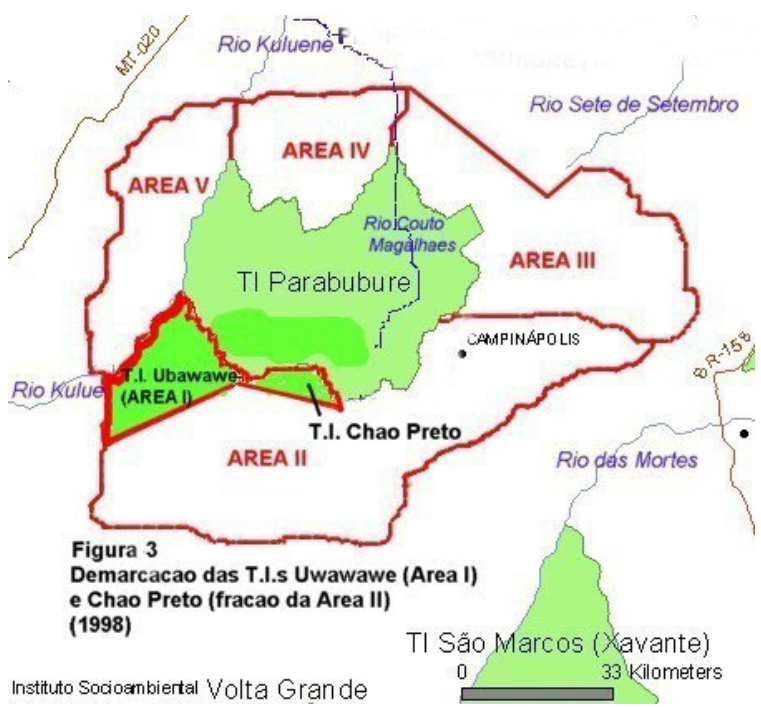

Fonte: De Paula, 2007. 
No mesmo ano ainda, um terceiro GT (GT-1998B) iria a campo, identificaria e delimitaria um pequeno trecho incrustrado na Área II, reivindicado por uma liderança Xavante que se opunha à demanda integral da Área II. A FUNAI, em uma mesma espécie de "rito sumário demarcatório" que legitimou a Área I, também regularizaria essa fração da Área II, para descontentamento geral de todos os grupos locais Xavante que reivindicavam as demais áreas, em particular, o grupo local que reivindica, até os dias de hoje, a totalidade da Área II. Note-se: os não-índios que ocupavam ambas as áreas demarcadas, nisso que estão chamando de "ritos sumários", receberam prontamente as indenizações sobre as benfeitorias a que tinham direito, retirando-se de maneira pacífica e rápida, algo totalmente fora dos padrões existentes em processos demarcatórios de terras indígenas, ainda mais as reivindicadas pelos Xavante.

Essa estratégia do órgão indigenista e seus efeitos sobre ramificações político-administrativas pouco ou nada visíveis espalhadas por outros órgãos estatais federais, estaduais e municipais, parece associada - para relembrar um dos motes do artigo - à fórmula do "dividir para imperar". Por um lado, estimulou, num primeiro momento, a tradicional dinâmica política fragmentária que marca a estrutura social Xavante, propiciando a legitimidade jurídica (a divisão das demandas em cinco áreas com suas respectivas lideranças indígenas) para que esses representantes e seus grupos locais de Parabubure participassem ativamente da mediação junto a distintas esferas do órgão indigenista (tantos regionais como na sede em Brasília). Por outro lado, daí a complexidade presente nessa dinâmica socioespacial, se a intenção do órgão indigenista era a de causar contradições no processo de regularização fundiária - por exemplo, com os ritos sumários demarcatórios de uma das áreas ( a Área I) e de uma fração de outra (da Área II), os demais grupos locais Xavante continuariam pressionando a FUNAI pela regularização das outras quatro áreas restantes.

\section{A RETOMADA DO PROCESSO DE REVISÃO DE LIMITES DA T.I. PARABUBURE (2000- 2003)}

Entre 2000 e 2003, a partir da nova onda de pressão sobre o órgão tutelar por parte dos grupos locais Xavante de Parabubure não contemplados nos processos de identificação anteriores, novos grupos de trabalho são criados para a identificação das Áreas II (em sua integralidade), III, IV e V9 . Lembro ao leitor que, além da Área I regularizada em sua integralidade, apenas uma pequena fração da Área II fora regularizada (a denominada T.I. Chão Preto).

O primeiro encontro do GT-2000 com as lideranças de grupos locais Xavante que reivindicavam revisões de limites territoriais não se deu em suas aldeias ou mesmo cidades próximas às suas terras indígenas, mas sim na sede da FUNAI em Brasília. Os encontros contavam com a equipe do GT e algumas lideranças Xavante pertencentes a cada uma das quatro áreas reivindicadas. Em outras palavras, nunca a equipe do GT conseguiu reunir todas as lideranças Xavante da T.I. Parabubure para debater o contorno integral das quatro reivindicações territoriais ainda restantes (o que não significa que elas não dialogassem entre si, com pactuações e atritos).

Uma vez em campo, o grupo de trabalho se deparou com os chefes Xavante ${ }^{10}$ endereçando, em uma performance bastante ritualizada, críticas contundentes a FUNAI. Vejamos alguns trechos discursivos de algumas lideranças: 
“A FUNAI veio aqui faz quatro anos. Veio por causa da política e não pelos índios. Só enrolando. Tem que incluir todas as áreas. Vocês só pensam em diárias" (CACIQUE J.L.).

“Já tivemos esse compromisso com o Sullivan [ex-presidente da FUNAI]. Nós somos os legítimos donos da terra. O Portugal invadiu o Brasil, o índio já estava no Brasil. Agora já está tudo virando deserto. Já faz quatro anos que está parado essa ampliação” (CACIQUE J.).

"Precisa arredondar todas as áreas... $O$ índio não cria a riqueza. $O$ rico do índio é a terra, animais, as frutas, os peixes. Precisamos de áreas para caçar, para fazer a caçada para a festa de casamento dos jovens. O índio está envolvido com o branco. Precisamos de mais terra para aumentar a caça. A área V está tudo quase destruído, os fazendeiros jogaram veneno que mata os bichos" (CACIQUE H.).

“Fazendeiro vai ser pago? Terra foi tudo contaminada, não tem quase mais caça, não tem mais sucuri para comer. Então paga logo para fazendeiro e manda embora" (CACIQUE C.).

Foram muitas as reuniões preparatórias para atingir o "consenso" entre os grupos locais Xavantes (em "warãs ${ }^{11}$ improvisados") sobre as fronteiras territoriais a serem demandadas e consolidadas para cada uma das quatro terras reivindicadas. Normalmente, a primeira parte das reuniões era dedicada a duras críticas à FUNAI, e, portanto, a nós, os membros do grupo de trabalho.

Essa nova etapa da identificação dos limites das quatro áreas restantes e contíguas a T.I. Parabubure teria tudo para caminhar para um simples preenchimento das lacunas existentes no relatório original de identificação elaborado pelo GT-1996. Entretanto a necessidade de se cumprir com maior rigor ainda os critérios previstos no artigo 231 da Constituição Federal, levou o GT-2000 (e, posteriormente, o GT-2003) a elaborar novas (e mais extensas) propostas de configuração para os limites das áreas reivindicadas, dando ênfase à associação entre aspectos da tradicionalidade da ocupação atual das áreas reivindicadas, o impacto do aumento populacional indígena sobre o ecossistema territorial e um extenso diagnóstico das condições ambientais da região na qual a T.I. Parabubure se localiza. Passo a sintetizar como se deu esse processo em cada uma das quatro áreas reivindicadas.

\section{IDENTIFICAÇÃO E DELIMITAÇÃO DA ÁREA V - GT/2000}

“Até aqui estava indo tudo bem”. Essa fala de um funcionário da FUNAI regional, com ares de repreensão aos trabalhos desempenhados pelo grupo de trabalho, revelaria uma contradição que estava minando por dentro o poder de controle tutelar: a contratação de antropólogos e ambientalistas não pertencentes aos quadros técnicos da FUNAI estaria provocando um descontrole da estratégia pela qual o órgão tutor vinha encaminhando, havia pelo menos 50 anos, a luta pela terra empreendida pelos grupos locais Xavante. Os exemplos das demarcações sumárias das terras indígenas Chão Preto e Ubawawe ${ }^{12}$ foram, ao que tudo indica, uma manifestação explícita desse desejo de controlar os processos de reivindicação territorial Xavante dentro de um claro paradigma colonial estabelecido desde o segundo contato ${ }^{13}$ de grupos locais Xavante com a sociedade nacional a partir da década de 1940. 
Vejamos o exemplo da Área V. No mapa abaixo, está apresentada a configuração final dos limites dessa área entregue à FUNAI pelo quarto grupo de trabalho (GT-2000) em 2001.

\footnotetext{
Figura 7 - Proposta original (1996) em vermelho; e em azul, a proposta de reconfiguração da Área V consolidada pelo GT-2000
}

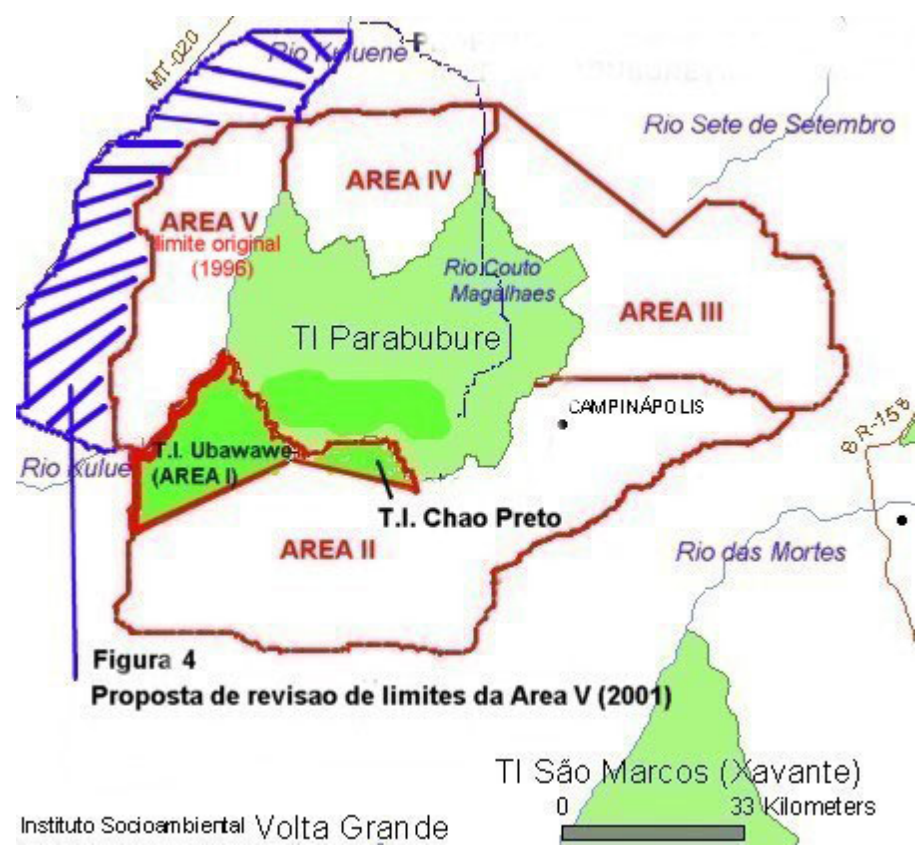

Fonte: De Paula, 2007.

Importante destacar que o aumento da Área V (em azul) pautou-se fundamentalmente pela observação do critério constitucional que define que são terras indígenas aquelas também "imprescindiveis à preservação dos recursos ambientais necessários ao bem-estar". Enquanto o primeiro GT (de 1996) não incluía as cabeceiras de diversos afluentes que constituem a cabeceira do Rio Kuluene (rio estratégico que, com suas ramificações, banha diversas aldeias da T.I. Parabubure), nesse elas são incorporadas enquanto fronteiras jurídicas fundamentais à preservação do bem-estar do grupo.

\section{IDENTIFICAÇÃO E RECONFIGURAÇÃO DOS LIMITES DA ÁREA IV - GT-2000}

O processo de identificação da Área IV se deu conjuntamente com a identificação da Área V durante os anos de 2000 e 2001. Interessante observarmos como nesse processo emergiu uma forte associação entre a lógica espacial Xavante e o seu complexo sistema de nominação (fenômeno sociológico este que, de fato, orienta todas as demais identificações). Um outro aspecto singular ali presente é que as negociações para produção das fronteiras dessa área (IV) destoou da rotina de controvérsias existentes entre grupos locais Xavante. Esse consenso pautava-se, por um lado, por conta dos limites dessa área ter sofrido pequenos acertos nesse novo processo de identificação e, por outro, porque esse grupo local era liderado por um chefe indígena de prestígio político interno muito elevado entre os Xavante. Este aspecto possibilitava a esse chefe Xavante conduzir o processo de mediação com o grupo de trabalho da FUNAI quase sem nenhum questionamento por parte de outras lideranças Xavante. 
Figura 8 - Reconfiguração da Área IV e sobreposição interna com a Área III (Letra A)

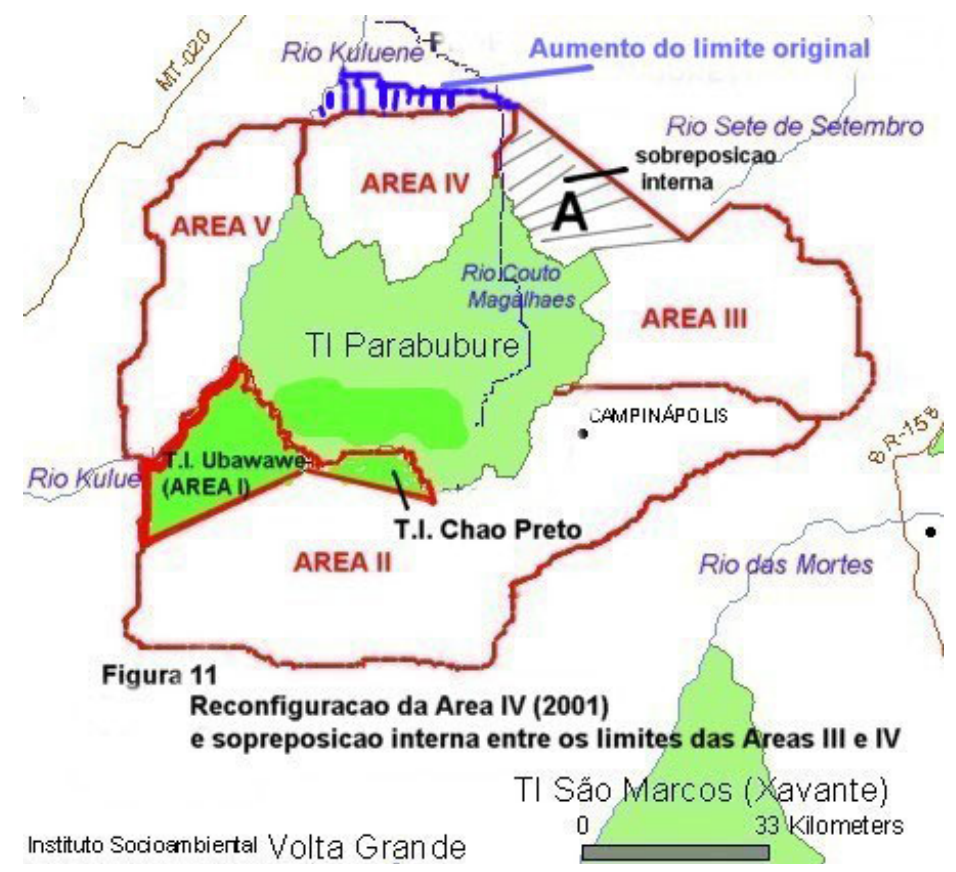

Fonte: De Paula, 2007.

Essa relativa estabilidade das fronteiras territoriais que compõe a Área IV sofreria um certo abalo durante o novo processo de identificação da Área III em 2003. O grupo de trabalho constatou que os limites pedidos pelos grupos locais que reivindicam, respectivamente, as Áreas III e IV se sobrepunham (Letra A na Figura 5), situação aparentemente conflituosa que remetia ao processo de regularização fundiária da T.I. Chão Preto (GT-1998B) e sua sobreposição a Área II (Ver Figura 3). Apesar da aparente semelhança, trata-se de sobreposições bastante diferentes. Enquanto a demarcação da T.I. Chão Preto redundou (ou, em outra perspectiva, consolidou territorialmente) em um conflito interno entre grupos locais Xavante, a sobreposição territorial verificada entre as Áreas III e IV acabou por reforçar com elementos etnográficos e históricos as demandas dos respectivos grupos locais Xavante. A explicação mais plausível para esse pacto interno advém de um dado etnográfico que pode ser captado em campo: aquela liderança de prestígio que mediava o processo de identificação da Área IV tinha livre trânsito entre todos os grupos locais Xavante de Parabubure. Essa liderança foi a única que participou ativamente dos processos de identificação e produção das fronteiras territoriais de três das quatro áreas reivindicadas, algo que não costuma coadunar com a lógica socioespacial-faccional e fragmentária Xavante.

Não há espaço aqui para me alongar nesse aspecto da etnologia Xavante, mas essa liderança era neto de Rai 'ri'té, o ancestral fundador de um dos "troncos" de maior prestígio político entre os Xavante de Parabubure $(\text { Lopes da Silva,1980 })^{14}$. Não por acaso, em um dos sítios arqueológicos que foi identificado em uma das fazendas situadas dentro dos limites territoriais demandados para a Área IV, encontra-se o cemitério no qual está enterrado o corpo de Rai'ri'té, o ancestral fundador. Esse fato seria apenas mais um acontecimento de praxe a compor os trabalhos de identificação, a não ser pelo fato do neto - representante máximo dos grupos locais que reivindicam a Área IV - "cuidar", em suas próprias palavras, desse cemitério desde 1978, fato confirmado de maneira mais do que inusitada pelo gerente da referida fazenda. 


\section{IDENTIFICAÇÃO E RECONFIGURAÇÃO DOS LIMITES DAS ÁREAS II E III- GT-2003}

Diferentemente do que ocorrera na Área V - que teve seus contornos originais ampliados pelo GT-2000 (ver figura 4), os limites da Área III seriam também redimensionados pelas lideranças Xavante, entretanto, tendo por base uma nova proposta que reduziria quase pela metade o tamanho da área proposta originalmente pelo GT-1996. Como será visto daqui a pouco, tratou-se de um movimento de redução análogo ao que ocorreria com os limites originais da Área II. Ao que tudo indica, as referidas pressões políticas anti-indígenas desencadeadas na região (e também diretamente sobre o órgão indigenista) desde o primeiro GT em 1996, conquistavam resultados. No mapa abaixo (figura 6) está indicada o trecho reduzido por iniciativa dos grupos locais Xavante que reivindicavam a Área III.

Figura 9 - Reconfiguração dos limites da Área III (2003)

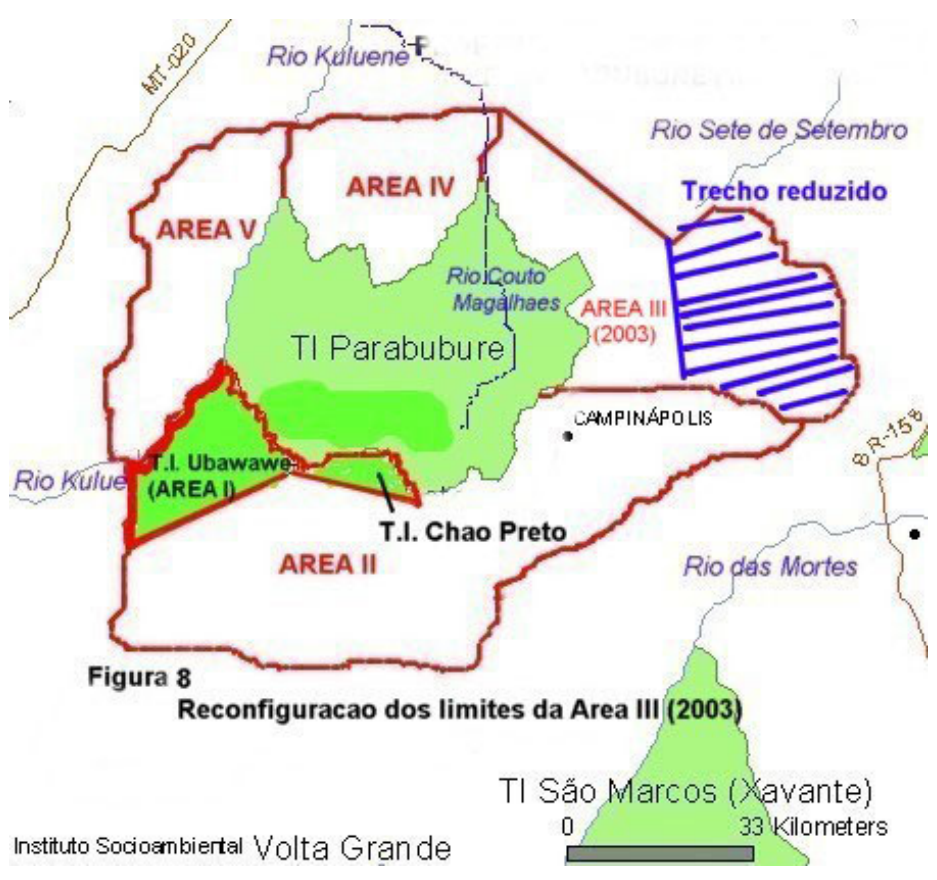

Fonte: De Paula, 2007.

Durante a operacionalização em campo desse derradeiro GT (2003), boatos sobre a possível desistência por parte das lideranças Xavante dos pedidos de identificação das Áreas II e III chegavam cotidianamente ao grupo de trabalho. As notícias diárias sobre a ameaça de agressão de regionais da cidade de Primavera do Leste contra outro GT de Identificação que trabalhava na Terra Indígena Sangradouro somada ao quadro político daquele momento serviram para alertar que provavelmente o GT enfrentaria maiores dificuldades em campo do que em outros GTs ${ }^{15}$.

Interessante relembrar a reprodução das performances rituais agressivas por parte das lideranças Xavante em meio às reuniões de preparação que antecediam as saídas a campo dos grupos de trabalho.

“Terra Xavante é tudo lugar. Rio das Mortes, Rio Araguaia."

"Governo deu terra de cascalho para o Benedito (Roadzo). Precisa devolver terra tradicional"

“ Rio Matrinchã. Noidore. Sepulcro sagrado. Tudo nosso.” 
"Faz 15 anos que damos prazo para regulamentar. E cada vez mais entra posseiro. Branco parece formiga".

“ Não é para dar terra! É para devolver a terra!”

“Votamos no Lula e ele vai resolver".

"Em lugar de agradecimentos ao índio, queremos a terra".

“Não mexemos no RJ, SP, BA. Mexemos no pedaço Mato Grosso, que é nosso"

"Vamos prender vocês aqui. Vocês só ganham diárias!"

É importante ressaltar que falas como "Terra Xavante é tudo lugar. Rio das Mortes, Rio Araguaia" e "Não mexemos no RJ, SP, BA. Mexemos no pedaço Mato Grosso, que é nosso", são pistas substanciais para compreendermos de que maneira os Xavante concebem aquilo que eles têm traduzido pela noção de "território tradicional". Ressalto também que a menção ao fato do "governo ter dado terra de cascalho para o Benedito" faz alusão à saga heroica do primeiro líder Xavante que retornara à região de Parabubure mais de 10 anos após os Xavante terem sido dali expulsos ${ }^{16}$.

Ao mesmo tempo, de maneira contraditória e confusa, no decorrer dessas reuniões, o GT foi percebendo que a decisão de realizar o novo processo de identificação tinha sofrido algum tipo de esmorecimento, principalmente, por parte do grupo local Xavante que reivindicava a Área II.

Demonstrando o grau de pressão política que os Xavante têm sofrido por parte de segmentos não-indígenas desde que resolveram intensificar a reivindicação de parte daquilo que consideram seu território tradicional, os discursos realizados por suas lideranças variaram de ameaças de guerra contra os "brancos" - se não houvesse a recuperação das terras que eles reivindicavam - para uma postura conciliatória, quase de desistência. Nessas interlocuções e variações em relação à certeza de levar adiante o processo de identificação, apareceria a referência a uma suposta "proposta do Governador". Essa suposta "proposta" fazia menção aos constantes boatos ouvidos em campo de que "o Governador do Mato Grosso" (na época, Blairo Maggi) estaria disposto a investir nas terras indígenas do Estado, através de insumos agrícolas, maquinário etc., desde que as populações indígenas ali localizadas, não só os Xavante, abandonassem seus pleitos territoriais ${ }^{17}$. Após intensas discussões entre as lideranças ali presentes, foi decidido num primeiro momento que "não adiantava realizar o trabalho", pois os "políticos do Mato Grosso não iam deixar ir para frente", além de que a FUNAI não teria "dinheiro para indenizar os fazendeiros". Prefeririam, assim, optar pelo "desenvolvimento das reservas", adotando, pois, a suposta proposta do governo estadual. Os maiores entusiastas do trabalho de identificação ali presentes, após o fim da reunião não consensual, ficaram sentados no meio do pátio, bastante desolados.

Entretanto, numa nova reviravolta, dois dias depois dessa última reunião com representantes Xavante de ambas as áreas, chegava de volta de Brasília um dos chefes Xavante de maior prestígio político entre todos os Xavante (inclusive, entre a população de outras de suas terras), além de ser o principal mediador junto à FUNAI do processo de identificação da Área II. Como a decisão de desistir do processo fora tomada sem a sua presença, foi pactuado entre essa liderança, seu grupo local e o grupo de trabalho que os trabalhos de identificação seriam realizados.

Não seria por acaso, então, que essa nova tentativa de identificação da Área II seria a mais problemática de todas, pois sua delimitação implicava na incorporação de áreas consideradas "urbanas" de dois municípios da região. 
Diante da pressão política local intermitente, o chefe político Xavante acabou apresentando uma nova proposta para o GT, pela qual reduzisse os limites originalmente propostos pelo GT-1996. Nessa nova proposta são excluídos pequenos trechos do pedido original - marcados no mapa abaixo (figura 7) —, estratégia nitidamente construída com o objetivo de atenuar o impacto fundiário do pleito sobre os municípios e diminuir, portanto, a pressão política local.

Figura 10 - Identificação e reconfiguração dos limites da Área II (2003)

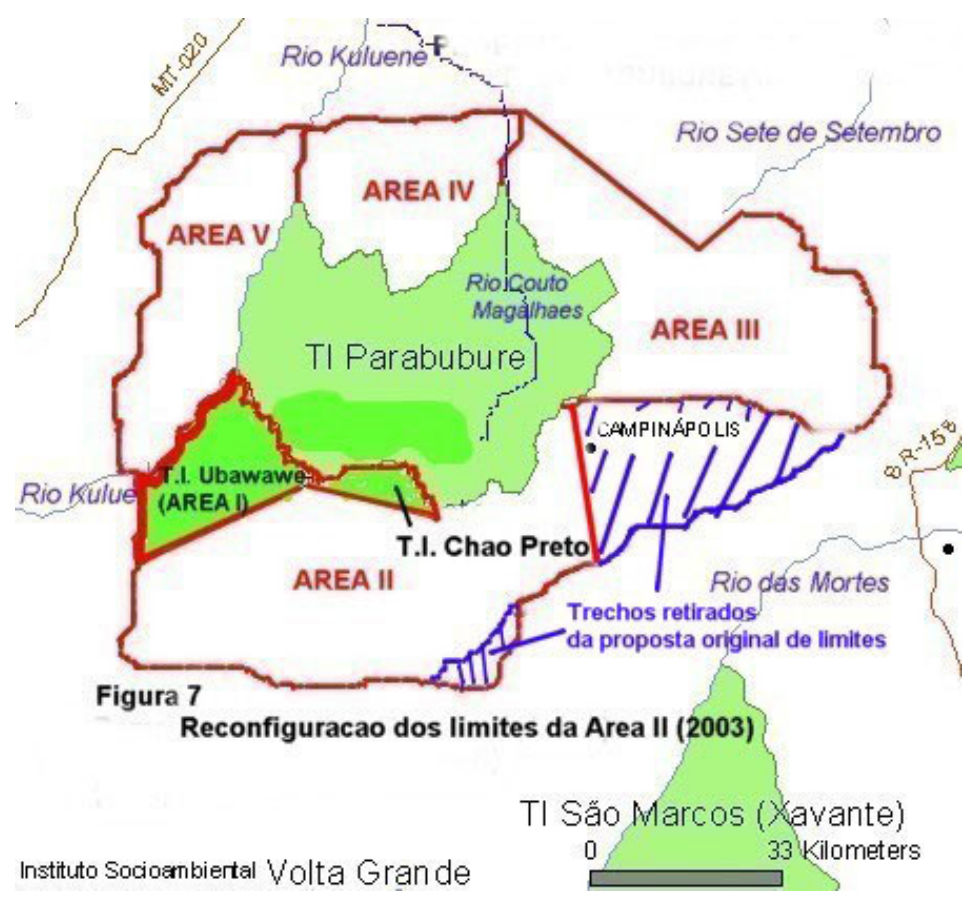

Fonte: De Paula, 2007.

Os setores regionais anti-indígenas não se deram por satisfeitos com esses recuos e continuaram sua estratégia tanto de conquista da opinião pública regional, como também pela tentativa de "sensibilização" da FUNAI para que fosse suspenso o conturbado processo de revisão de limites da T.I. Parabubure que, naquele momento, já se arrastava por quase 20 anos (desde os primeiros pedidos de revisão que chegaram a FUNAI em 1985). As articulações de bastidores existentes entre esferas administrativas regionais e federais para efetivar essa protelação foram inúmeras e se encontram devidamente registradas na já vasta documentação que compõe a história oficial desse longo processo de identificação de terras indígenas ${ }^{18}$. É importante ressaltar que nessa documentação oficial encontram-se presente desde cartas e memorandos assinados pelas principais lideranças Xavante a respeito da condução — ou mesmo suspensão - dos trabalhos de identificação das áreas pretendidas, como documentos expedidos por inúmeros setores não-indígenas contrários aos processos de identificação e endereçados à FUNAI.

\section{OS XAVANTE E O "MUNDO DOS BRANCOS".}

Os grupos locais Xavante conhecem profundamente a "biografia" de cada um dos seus vizinhos não-índios, desde grandes fazendeiros a aglomerados de pequenos sitiantes: "aquele veio do Rio Grande do Sul"; "aquele outro tinha um frigorifico no interior de São Paulo que faliu"; "aqueles chegaram ontem, são piores do que fazendeiro, pois comem nossa caça". O inverso também é 
absolutamente verdadeiro: alguns fazendeiros e pequenos ocupantes da região dizem que estão cansados de doar pães, cabeças de gado e aves para distintos caciques Xavante que batem às suas portas em diversas ocasiões, tais como o "Dia do Índio" ou nas "festas de fim de ano". Ficam chocados quando, depois de tantos presentes, descobrem que os mesmos caciques reivindicam as terras que ocupam.

Os grupos locais Xavante também caçam, pescam e coletam em todas as propriedades circunvizinhas à atual Terra Indígena Parabubure. Portanto, na perspectiva exigida pelo parágrafo 1 do artigo 231 da Constituição Federal de 1988, há também muitos elementos para que as quatro áreas reivindicadas pelos grupos locais Xavante de Parabubure sejam classificadas como terras tradicionalmente ocupadas na atualidade. Literalmente, os Xavante "pulam as cercas" que os separam do que consideram seus territórios tradicionais.

Um dos caciques que nos acompanhava em uma das identificações resumiu a reação dos Xavante à proibição de caçar — ordem expressa de muitos fazendeiros ou mesmo pelos "fiscais do IBAMA" - com o seguinte raciocínio: "O veado está marcado com o nome deles? Não!... Os bichos são dos índios." A exigência por parte dos Xavante para caçar durante todo o trabalho de identificação chegou a propiciar momentos de tensão. Chegamos a intervir de maneira rigorosa, quando foi possível, impedindo que eles caçassem nas fazendas nas quais tínhamos pontos a identificar, com o argumento que essa atitude poderia servir de pretexto para que os gerentes inviabilizassem nosso trabalho. Sempre bastante contrariados, em alguns casos eles concordavam com nossa orientação, mas aproveitavam para tecer comentários sarcásticos tais como, "Eles [os membros do GT] são amigo do Ibama!". Apesar desse esforço por parte do GT, em muitos casos, os Xavante, sem titubear, exigiam (e eram atendidos) que parássemos o carro para que pudessem efetuar suas caçadas.

Em um momento dos trabalhos de identificação, ocorreu uma discussão bastante tensa entre um gerente e duas lideranças Xavante por conta da necessidade de identificar um dos cemitérios em uma das fazendas da região. $\mathrm{Na}$ discussão, aliás, foi necessária a intervenção de membros do GT para que a situação não descambasse para algo mais grave, pois ambos os lados, como fomos perceber depois, estavam armados (alguns Xavante andam com armas e munição para caça). Destacou-se em meio a essa tensa discussão um argumento que expressa a percepção que os Xavante, de modo geral, têm em relação às terras adjacentes àquelas já reconhecidas como suas pelo estado brasileiro. Um velho Xavante se dirigiu ao gerente e perguntou:

"Seu bisavô morou aqui? Eu não conheci. Seu avô morou aqui? Eu não conheci. Seu pai morou aqui? Eu não conheci. Meu bisavô morou e andou por tudo isso aqui...meu avô...meu pai...Volta para onde você veio. Você é lá do Rio [Grande] do Sul..(em alusão ao fato do gerente ser gaúcho)."

Note-se que o argumento central da liderança Xavante gira em torno da imemorialidade da ocupação tradicional, perspectiva essa muito arraigada nos discursos dos velhos Xavante. Um dos grandes exercícios pedagógicos ocorridos no andamento dos GTs foi o de explicar aos grupos locais Xavante que, apesar de fundamentais, somente os argumentos de imemorialidade da ocupação não bastam para atender os critérios exigidos para demarcação de terras indígenas pelos diplomas normativos.

De maneira geral, a rivalidade entre o autointitulado "setor produtivo" e os grupos locais Xavante tem por base, fundamentalmente, visões totalmente 
distintas em relação às formas de apropriação da terra, ou, numa fórmula mais antropológica, do exercício de diferentes e antagônicas territorialidades.

A monotonia das extensas áreas de agricultura e de pastagens (muitas, infestadas de cupins, fato que só revela a exaustão do solo) ao longo das estradas contrasta com a exuberância da mata que recobre as terras indígenas Xavante de maneira geral. Dentro da Terra Indígena Parabubure, retomada por grupos locais Xavante na década de 1970, as antigas áreas de pastagens encontram-se num processo intenso de recuperação da vegetação do cerrado original, sendo que quanto mais caminhamos em direção ao seu centro, mais exuberante torna-se a mata.

Não há dúvida de que uma das maiores experiências que se pode ter em um GT de identificação com participação Xavante é a descoberta, e o decorrente convencimento, de que, por detrás da aparente semiaridez do cerrado brasileiro, esconde-se uma biodiversidade exuberante, percepção contrária à imagem bastante difundida no e pelo senso-comum de que se trata de um habitat "pobre" e, portanto, destinado a ser extinto para que seja transformado naquilo que seria num imenso "celeiro de grãos para exportação".

Em uma rápida conversa travada pela equipe do GT com um grupo de fazendeiros da região, ficou patente o "diálogo entre surdos" que acontece em situações como esta. "Agora não tem nada mais lá", disse o fazendeiro, referindo-se às antigas áreas de pasto que estão atualmente dentro da Terra Indígena Parabubure, nas quais o cerrado vai se recuperando lentamente. Um dos representantes Xavante na equipe prontamente respondeu: "Tem cerrado, tem caça!".

Esse desencontro de visões a respeito da melhor forma de se apropriar do cerrado expressa a contradição primeira que tem colocado índios e não-índios em conflito há dezenas de anos nessa como em outras regiões do Brasil. De um lado, grandes produtores rurais advindos de outras regiões do país e pequenos produtores cheios de ilusões, que, incentivados por políticas públicas levadas a cabo pelas administrações federal e estadual há décadas, enxergam o cerrado como "um matagal" a ser derrubado e substituído pela produção agrícola e pelas pastagens. Do outro, a população indígena local, que vê esse bioma brasileiro como fonte insubstituível para a reprodução de suas formas indígenas de apropriação territorial, não só em termos de subsistência física, como também cultural - cultura vivida intensamente, seja no dia a dia da aldeia, seja em ocasiões cerimoniais.

O sentimento que os velhos Xavante transmitem é que a felicidade pela recuperação de um pedaço de seus territórios se confunde a uma espécie de frustração por perceberem que o confinamento a limites propiciados por uma lógica espacial antagônica as suas é algo inexorável. Eles insistentemente falavam entre si de quando eram wapté [adolescentes] e "andavam lá pelo Xingu, depois da Gaúcha (do Norte)..." De certa forma, esse sentimento de confinamento acaba por ser também responsável pela agressividade com a qual os Xavante mais velhos costuma expressar suas reivindicações de recuperação territorial, seja na sede da FUNAI em Brasília, seja junto aos "gerentes" das fazendas vizinhas.

Não é por acaso que um dos caciques nos afirmou que eles, os velhos, têm plena consciência de que a possibilidade de reconquistarem partes do seu "antigo território" está cada vez mais difícil - "os brancos são que nem formiga, são muitos, derrubam tudo". Grande parte das lideranças mais velhas - em média com 60 anos - tem gravado na memória todo o processo de expulsão dos grupos locais Xavante da atual região de Parabubure ainda na década de 1950. 
Mas do que isso, foram eles que - asilados durante uma década nas missões salesianas e nos postos do SPI - iniciaram a saga de recuperação de seus territórios tradicionais a partir do final da década de 70. Se há uma dimensão da situação etnográfica na qual podemos encontrar expressões que fazem alusão ao processo de produção de uma idéia que hoje se denomina como "território tradicional Xavante" é quando se convive com essas lideranças. Essas gerações mais velhas foram socializadas em espaços nos quais as suas atuais nove terras, incluindo Parabubure, são apenas frações territoriais, diferentemente das gerações mais novas, nascidas e confinadas em "situação de reserva".

\section{CONSIDERAÇÕES FINAIS}

Temos mesmo que escolher teoricamente entre estrutura e história, sincronia e diacronia, modelo e ação, regra e improvisação? Acho que não. Acho, pelo contrário, que é de suma importância evitar o Scylla do estruturalismo sem naufragar no Charybdis do transacionalismo. (Maybury-Lewis,1988:120)

Busquei no decorrer deste artigo apresentar, fundamentalmente, uma das dimensões da complexa dinâmica socioespacial Xavante ao dar ênfase às negociações e articulações envolvidas na produção de fronteiras territoriais numa situação etnográfica extraída a partir da minha experiência em processo de identificação de terras. A partir dessa vivência turbulenta e em um esforço retrospectivo, tentei organizar o material etnográfico captado naquela situação e busquei compreender os significados embutidos no comportamento fragmentário dos grupos locais Xavante diante do processo de revisão de limites da T.I. Parabubure.

Como fator complicador a mais nesse quebra-cabeça fundiário, como foi demonstrado fartamente no decorrer do artigo, vale reafirmar que os grupos de trabalho se defrontaram com a oposição por parte de alguns dos grupos locais Xavante diante das variadas propostas de reconfiguração dos limites de algumas das quatro áreas em processo de (re)identificação. Muitas dessas oposições ou questionamentos em relação às propostas de delimitação que os GTs conseguiam produzir contextualmente ao final de dias e dias de trabalho, estavam associadas, como vimos, a pressões políticas de atores não-indígenas interessados em desestabilizar a tensa e já difícil relação dos grupos de trabalho com os grupos locais Xavante. No mesmo registro, as disputas acirradas entre os grupos locais de Parabubure - que passavam horas, às vezes, dias, discutindo em língua materna as fronteiras internas (e suas potenciais sobreposições) de cada uma das quatro áreas em identificação -, continuariam a se desenrolar tanto no decorrer do próprio trabalho de campo, como, em alguns casos, nos corredores e gabinetes da FUNAI ${ }^{19}$. Por outro lado, como já afirmado no artigo, o balizamento constitucional estabelecido pela $\mathrm{CF} / 1988$ - e do qual se não o GT, pelo menos, sua coordenação antropológica, é o portador natural nesse tipo de situação - trazia para campo uma espécie de "freio e contrapeso" às pressões e investidas dos poderes locais anti-indígenas responsáveis por estimular a dinâmica socioespacial fragmentária Xavante ${ }^{20}$. Curiosa inversão na qual o Estado, representado pelo GT, participa de um processo conflituoso entre índios e não-índios e acaba por reforçar os interesses dos primeiros em detrimento dos segundos, pelo menos em uma de suas etapas mais estratégicas, o processo de identificação de uma terra indígena.

Importante realçar que meu envolvimento com essa situação etnográfica complexa e multifacetada jamais indicou a presença de uma possível lógica espacial Xavante de cunho "expansionista" e ilimitada como quer nos fazer 
acreditar, por exemplo, a mídia regional (ver Seção II). Muito pelo contrário, os dados históricos e etnográficos - fartamente apresentados na pesquisa que deu origem a esse artigo - demonstram que, a partir do final do século XIX, os grupos locais Xavante ocuparam um determinado conjunto de territórios locais visivelmente articulados e delimitados no leste mato-grossense, com fronteiras bastante definidas e, surpreendentemente, reconhecidas oficialmente pela Fundação Brasil Central, portanto, pelo Estado brasileiro, no início da década de $1950^{21}$.

Figura 11 - "Das Terras dos Índios situadas entre os rios das Mortes o Rio Kuluene"

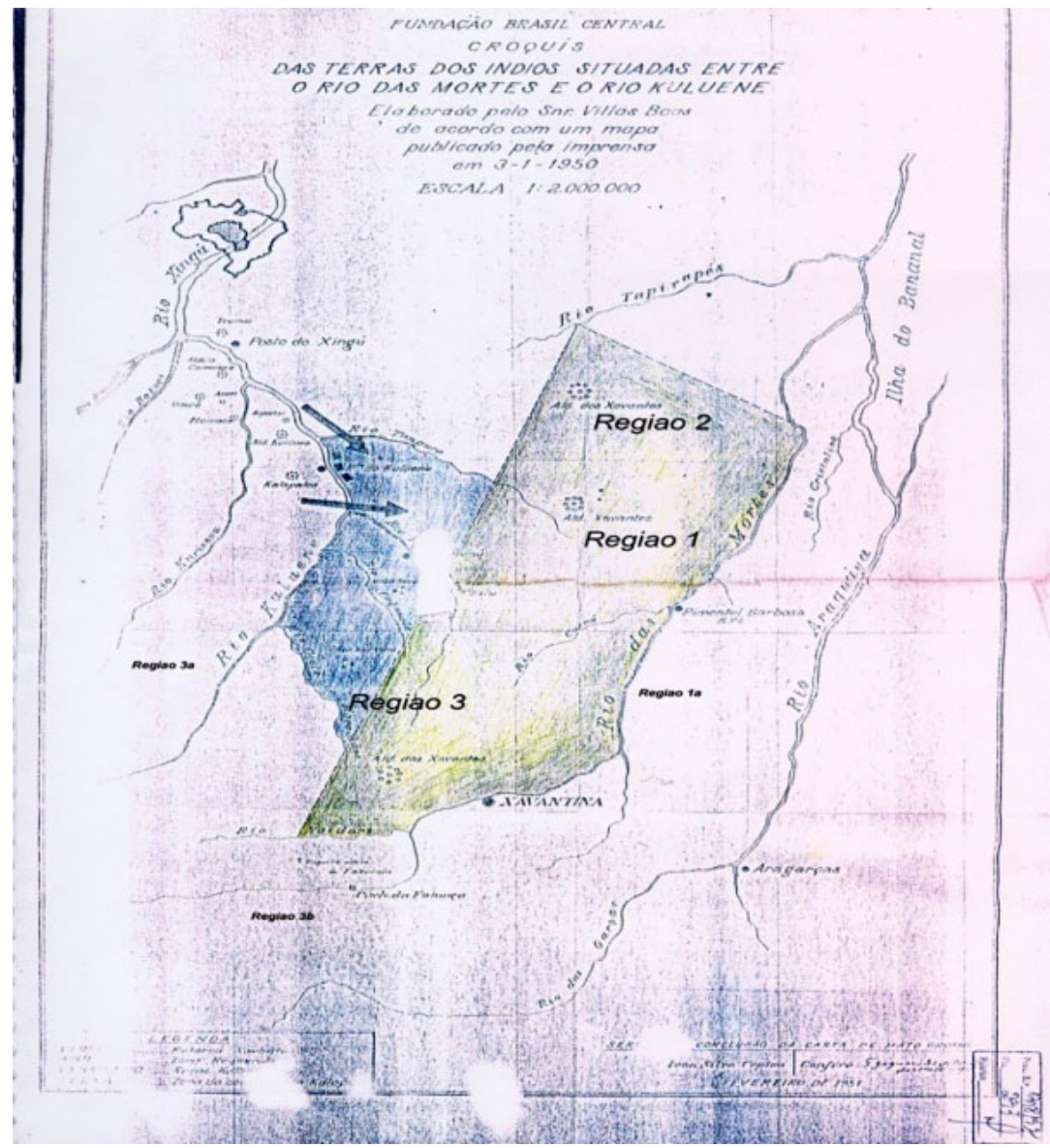

Fonte: SPDOC/FUNAI - De Paula, 2007

Expulsos de seus territórios de maneira violenta, perversa e arbitrária entre as décadas de 30 e 50 do século passado, os diversos grupos locais Xavante que constituem a "Sociedade Xavante" (MAYBURY-LEWIS, 1984), passaram a retornar e recuperar esse conjunto de territórios a partir da década de 60 numa saga para lá de heroica ${ }^{22}$.

Nesse registro, procurei demonstrar que todas as reivindicações atuais de revisão de limites de Parabubure assentam-se numa concepção de "recuperação" de um "território" (ou de alguns territórios). Em outras palavras, a situação etnográfica vivenciada por mim como antropólogo-identificador não foi marcada pela inexistência de uma concepção nativa de "território" - leia-se, "com fronteiras externas definidas" ou "contínuo" — , e sim pelos inúmeros problemas sociopolíticos derivados justamente da instauração de uma nova relação dos grupos locais Xavante com seu território: a imposição de uma descontinuidade territorial pelo Estado ao longo de décadas que impede o livre 
desenvolvimento da dinâmica socioespacial Xavante e da sua necessária associação a um território contínuo.

A imagem de uma territorialidade sem limites, ameaçadora da "soberania nacional", tal qual vimos brevemente no início do artigo, é profundamente exotizante e sua reprodução atende diretamente a interesses anti-indígenas.

É certo também que as fronteiras desse "território" a ser recuperado têm sido pensadas pelos grupos locais Xavante no bojo de um processo intenso de "reelaboração da cultura e da relação com o passado" (OLIVEIRA, 1998) a partir, há que se notar, da instauração de novas relações entre a Sociedade Xavante e seu Território, e não de suas ausências.

Parece não haver dúvidas de que estratégias coloniais tardias do "dividir para imperar" foram implementadas pela FUNAI em seu relacionamento com os diversos grupos locais Xavante durante o longo período de tentativas de identificação das cinco áreas por eles reivindicadas. Entretanto busquei demonstrar que a aplicação dessa fórmula clássica do poder colonial entre os Xavante deveria ser relativizada: mesmo encontrando na dinâmica fragmentária que caracteriza a estrutura social Xavante um "terreno sociológico fértil" para germinar, a efetivação integral da dominação colonial em sua faceta de colonialismo interno não pode ser aceita como de mão única ou homogeneizadora (OLIVEIRA, 1998).

Numa avaliação confessadamente otimista, vale dizer que os grupos locais Xavante têm conseguido o reconhecimento de boa parte de suas demandas territoriais (e assistenciais) desde o início da retomada de seus direitos territoriais a partir da década de 1970. Pode-se inclusive pensar que a configuração sociológica fragmentária da "estrutura social Xavante" venha ser um dos fatores sociológicos mais importantes para a sobrevivência física e cultural desse povo até o presente momento ${ }^{23}$.

Por fim, numa espécie de "posfácio", no caso específico do estabelecimento das fronteiras territoriais nos processos de identificação das quatro áreas contíguas à Terra Indígena Parabubure - aqui fartamente descritos - $\mathrm{o}$ problema que mais salta aos olhos dos Xavante e de seus aliados é que grande parte das microbacias (onde as atividades de caça, pesca e coleta continuam a ser praticadas pelos grupos locais Xavante de Parabubure) está ocupada hoje por extensas fazendas cada vez mais voltadas ao agronegócio que, como se sabe, encontra-se associado a uma vasta cadeia de utilização de agrotóxicos, pesticidas e fertilizantes, reconhecidamente responsável pela degradação ambiental do cerrado mato-grossense ${ }^{24}$. A reprodução física e cultural do modo de vida Xavante dentro de seus "usos, costumes e tradições", como garante o artigo 231 da Constituição Federal de 1988, está claramente em xeque. Por outro lado, a parte invisível desse problema é a evidente, mas pouco "etnografável" (com o perdão do neologismo) força da articulação de atores econômicos e político-partidários anti-indígenas incrustrados nas administrações públicas (federal, estadual e municipal). Essa articulação que, como vimos, se torna menos implícita quando as mídias regionais veiculam pesadas matérias contra as reivindicações indígenas - ou mesmo quando os grupos de trabalho da FUNAI sofrem ameaças diretas de "autoridades" em campo —, tem implicado no que se costuma chamar nos corredores dos órgãos públicos de "engavetamento" dos processos de regularização fundiária. Não é por acaso que os relatórios de identificação e delimitação das quatro áreas contíguas à Terra Indígena Parabubure, produzidos pelos GTs de 1996, 2000 e 2003 e devidamente entregues à FUNAI em 2005, encontram-se esquecidos desde então em alguma de suas gavetas, apesar de terem sido objeto de pareceres favoráveis de setores do órgão indigenista ao final da década de $2000^{25}$. Em uma "estrutura da conjuntura" 
favorável aos interesses não-indígenas vigentes regional e nacionalmente, os grandes chefes Xavante de outrora, responsáveis diretos pela mediação do seu povo junto ao Estado nacional brasileiro no que diz respeito à recuperação de seus territórios tradicionais no leste mato-grossense, pararam, há mais de uma década, de realizar suas viagens diplomáticas e reivindicativas à Brasília. Estruturas e estratégias.

\section{NOTAS}

${ }^{1} \mathrm{O}$ primeiro grupo técnico, que foi responsável pela identificação e delimitação das denominadas oficialmente pela FUNAI "áreas IV e V", ficou 60 dias em campo (outubro-dezembro/2000). O segundo grupo de trabalho, responsável pela identificação e delimitação das denominadas “áreas II e III”, ficou 34 dias em campo (julho/agosto-2003). Posteriormente, tive que voltar por duas semanas a campo para ajudar na resolução de controvérsias existentes entre grupos locais Xavante sobre os limites/sobreposições das quatro áreas.

${ }^{2}$ O Decreto $n^{\circ} 1775$, de 8 de janeiro de 1996, dispõe sobre os procedimentos administrativos para demarcação de terras indígenas, estabelecendo o que ficou conhecido como o "princípio do contraditório", que, na perspectiva de seus produtores, possibilitaria aos "não-índios" que se sintam prejudicados pelas demarcações o direito à "ampla defesa". A Portaria 14, de 09 de janeiro de 1996, estabelece novas normas para a elaboração do relatório de identificação de terras indígenas, exigindo que sejam preenchidos os seguintes requisitos: (a) dados gerais sobre o grupo; (b) habitação permanente; (c) atividades produtivas; (d) meio ambiente; (e) reprodução física e cultural; (f) levantamento fundiário; (g) conclusão: limites pretendidos pelo grupo. Além desses dois decretos, foi elaborado pela FUNAI, em 1997, um roteiro para a atuação do grupo de trabalho em campo, conhecido como "Manual do Antropólogo". Para uma análise detalhada desses instrumentos jurídicos, ver Barreto Filho (2002).

${ }^{3}$ Investigação nessa mesma linha foi realizada por Fernandes (2005) tendo como foco a atuação de lideranças Xavante nos corredores da Funai em Brasília.

${ }^{4}$ Um balanço dessa produção é devidamente apresentado na introdução da tese de doutorado da qual esse artigo foi extraído.

${ }^{5}$ A maioria dos mapas que compõem o artigo foi trabalhada e estilizada a partir do "Mapa de Terras Indígenas no Brasil" produzido pelo Instituto Socioambiental (ISA).

${ }^{6}$ Portaria da FUNAI 344/PRES de 26.03.1996.

${ }^{7}$ A Terra Indígena Parabubure tinha sido regularizada em 1979, quando foram unificadas as terras indígenas Kuluene e Parabubure.

${ }^{8}$ Os TDA's são títulos de modalidade nominativa e negociável a taxa de juro de $6 \%$ (seis por cento) ao ano. De acordo com a quantidade de módulos rurais contidos na área desapropriada, o prazo para resgate pode ser de cinco, dez e vinte anos. São pagos anualmente, na data de aniversário que coincidir com a data de emissão do referido título. Esses títulos são moedas como o dinheiro, têm cotação em bolsa e são atualizados mensalmente pelo Governo Federal por meios de portarias". (Linhares,2000).

9 Portaria FUNAI 1086/PRES de 20.10.2000 (Áreas IV e V). Portaria FUNAI 592/ PRES de 20.01.2003 (Áreas II e III).

${ }^{10}$ A condição de "chefe" é o maior bem de prestígio disputado pelos homens maduros Xavante e suas facções. "Um chefe é reconhecido como tal enquanto é o cabeça de uma facção forte. Segundo o pensamento Xavante, se sua facção deixa de ser suficientemente forte e poderosa para mantê-lo naquela posição, ele perde o direito à chefia" (MAYBURY-LEWIS, 1984, 1967, p. 251).

11 "Warã" é o termo empregado pelos Xavante para designar o local no qual se reúne o "conselho dos homens maduros". Esses homens são responsáveis pelo gerenciamento coletivo das decisões mais importantes de um grupo local Xavante. Na morfologia da aldeia, os etnógrafos denominam essa formação socioespacial como "pátio central".

${ }^{12}$ Antigos indigenistas da FUNAI, de maneira informal, confidenciaram-me que a seleção de fazendas para a demarcação de terras Xavante no leste mato-grossense durante a década de 1970 e 80 era realizada a partir da discussão entre eles e a direção da FUNAI em Brasília. Para uma etnografia da administração pública na dimensão do indigenismo 
ver: Lima $(1995,1998)$.

13 "Segundo contato", pois antes da década de 1950, grupos Xavante tiveram intensas relações com segmentos da sociedade nacional ainda no século XVIII.

${ }^{14}$ No trabalho original do qual foi extraído o material etnográfico e reflexivo para esse artigo, há um capítulo dedicado somente a apresentação da estrutura social Xavante e suas articulações com o processo de produção de fronteiras territoriais. As linhagens e os "troncos" Xavante são elementos centrais para a compreensão dessa articulação.

15 Paralelamente, outros processos de identificação de áreas reivindicadas pelos Xavante da terras indígenas Sangradouro, Pimentel Barbosa e Areões foram realizados por outros grupos de trabalho, o que causou extremo alvoroço no leste mato-grossense. Daí as reações virulentas por parte da mídia vinculada aos grandes grupos econômicos regionais anti-indígenas e seus efeitos diretos nas pressões sofridas pelos membros dos grupos de trabalho em campo.

${ }^{16}$ A memória Xavante da ocupação territorial em termos históricos do leste mato-grossense tem como referência à travessia do Rio Araguaia, fato ocorrido, na perspectiva de alguns etnógrafos e historiadores, por volta do final do século XIX. Daí para trás, a história dessa ocupação sob o ponto de vista Xavante ganha contornos do que Lopes da Silva (1984) denominou como "a expressão mítica da vivência histórica”, fórmula recuperada e desenvolvida pelo autor (2007).

${ }^{17}$ Esse tipo de estratégia foi implementada pela FUNAI no final da década de 1970 a partir do conhecido "Projeto Xavante" que envolveu todas as terras Xavante (e também Xerente), com resultados deletérios para a formação econômico-social indígena tradicional, além de ter reforçado os laços assistencialistas entre os índios e o órgão tutelar mantidos desde os tempos do (re)contato.

${ }^{18}$ Todo antropólogo que participa de uma situação etnográfica com esse perfil tem o direito de ler toda a documentação presente nos processos administrativos referentes a cada pedido de revisão de T.I.s. Ou pelo menos, tinha.

19 Há uma vasta documentação nos arquivos da FUNAI elaborada pelas maiores lideranças Xavante de Parabubure que revelam motivos das divergências entre elas e seus grupos locais em relação a esse processo de revisão de limites (limites de cada uma das áreas reivindicadas; a legitimidade das lideranças que a solicitam; os nomes que cada área deve receber após a demarcação; dentre outros). Essa documentação manifesta, por outras vias, aspectos importantes da estrutura socioespacial Xavante.

${ }^{20}$ Foi assim que pude perceber que, desde a gênese desta "situação histórica" específica, por volta de 1985, a disputa de caráter intergrupal pela delimitação de fronteiras territoriais manifestou-se de maneira contundente, conflituosa e fragmentária, dinâmica essa que me surpreendeu, já que tinha como suposto etnográfico a seguinte fórmula: os processos de luta pela "terra" desencadeados pelos Xavante desde a década de 1970 se caracterizariam por uma [...] "unidade" raramente etnografada no decorrer do longo processo de contato deste povo com a sociedade nacional. (LOPES DA SILVA, 1980, p. 15, grifo meu).

${ }^{21}$ Além dos comentários críticos a este decreto realizados por Maybury-Lewis (1984, 1967) e Sbaderlloto (1996), diversos antropólogos que trabalham com diagnósticos ou processos de identificação de terras Xavante o apresenta como documento de, em tese, legitimidade da imemorialidade da ocupação.

${ }^{22}$ É importante ressaltar que a historiografia do contato dos Xavante com a sociedade nacional vem sendo aprofundada e complementada desde o roteiro básico apresentado por Maybury-Lewis (1984[1967]) em a "Sociedade Xavante". Correndo o risco de cometer injustiças, indicam alguns deles: Giaccaria\&Heide (1972), Ravagnani (1977), Farias (1990,1994), Lopes da Silva (1980,1983,1984,1992), Menezes (1984), Lopes (1988), Sbaderllotto (1996), Garfield (2001) e Coimbra\&Flowers\&Salzano\&Santos (2002). Outros antropólogos que têm participado de processos de identificação de terras indígenas xavante nas últimas décadas também seguem esse roteiro cada evz mais ampliado como são os casos dos relatórios de identificação produzidos por Eugênio Wenzel e Jorge Luiz de Paula (1998); Jorge Luiz de Paula \& Luís Roberto de Paula (2001); Luís Roberto de Paula (2005); Ricardo Calaça Manoel (2005).

${ }^{23} \mathrm{O}$ que nos faz relembrar a precisa, otimista e utópica fórmula clastreana da "conjuração do Um, do Estado” (CLASTRES,1990, p. 152). Lopes da Silva dedicou às páginas conclusivas de sua tese de doutorado para uma bela reflexão sobre esse tema. Ver também Vianna (2008) para uma leitura original sobre a estrutura social Xavante a partir 
da incorporação da prática do futebol.

${ }^{24}$ Fonte: Fórum Mato-Grossense de Combate aos Impactos dos Agrotóxicos. Disponível em: https:/g1.globo.com/mt/mato-grosso/noticia/2018/08/01/exposicao-ao-agrotoxico-em-mt-e-seis-vezes-maior-que-a-media-nacional-aponta-pesquisa.ghtml. Acesso em: 15 maio 2020.

${ }^{25}$ Faltando, portanto, apenas a assinatura de um de seus sucessivos presidentes para alcançarem o status normativo de "terra identificada", a primeira etapa mais consistente em termos jurídicos do longo processo de regularização fundiária de uma terra indígena.

\section{BIBLIOGRAFIA}

BRASIL. Constituição [1988]. Constituição da República Federativa do Brasil. Brasília, DF: Senado Federal: Centro Gráfico, 1988.

BALANDIER, Georges. A noção de situação colonial. Cadernos de Campo, n. ${ }^{\circ}$ 3. São Paulo: Edusp, 1993.

CLASTRES, Pierre. A Sociedade contra o Estado. São Paulo: Francisco Alves, 1990.

CHOVELON, Hipólito; FERNANDES, Francisco; SBARDELLOTTO, Pedro. Do primeiro encontro com os Xavante à demarcação de suas reservas. Campo Grande: Missão Salesiana, 1996.

COIMBRA JÚNIOR, Carlos Everaldo Álvares; FLOWERS, Nancy M.; SALZANO, Francisco Mauro; SANTOS, Ricardo Ventura. The Xavante in transition: health, ecology and bioanthropology in Central Brazil. Ann Arbor: Univers. of Michigan Press, 2002.

DE PAULA, Luís Roberto. Travessias: um estudo sobre a dinâmica sócio-espacial Xavante. 2007. Tese de Doutorado em Antropologia Social - Faculdade de Filosofia, Letras e Ciências Humanas, Universidade de São Paulo, São Paulo/ SP, 2007.

FERNANDES, Estevão Rafael. Entre cosmologias, estratégias e performances: incursões Xavante à Funai. Dissertação (Mestrado). Dissertação de Mestrado Programa de Pós-Graduação em Antropologia Social, Universidade de Brasília, Brasília/DF, 2005.

FERREIRA, Andrey Cordeiro. Colonialismo, capitalismo e segmentaridade: nacionalismo e internacionalismo na teoria e política anticolonial e pós-colonial. Soc. estado, Brasília, v.29, n. 1, p. 255-288, abr. 2014. Disponível em: https:// www.scielo.br/scielo.php?script=sci_arttext\&pid=S0102-69922014000100013. Acesso em: 08 mar. 2019.

FILHO, Henyo T. B. Disciplinado a Diversidade Cultural: uma perspectiva antropológica sobre a Portaria 14. Revista de Estudos em Relações Interétnicas, v. 6, n. $1,2002$.

FUNAI. Relatório de Identificação e Delimitação das Áreas II, III, IV e V (Terra Indigena Parabubure/Xavante. Brasília, DF: FUNAI, 2005.

FUNAI. Relatório de Identificação e Delimitação das áreas pretendidas pelos Xavante da Terra Indígena Pimentel Barbosa e Areões. Brasília, DF: FUNAI, 2005.

154 FUNAI. Relatório de Identificação e Delimitação das Áreas IV e V (Terra Indigena Parabubure/Xavante. Brasília, DF: FUNAI, 2000/2001.

FUNAI. Relatório de Identificação e Delimitação das Áreas 2 e 3 (Terra Indígena Parabubure/Xavante. Brasília, DF: FUNAI, 1998.

GARFIELD, Seth. Indigenous struggle at the heart of Brazil: state policy, frontier expansion, and the Xavante indians, 1937-1988. Durham: Duke University Press. (2001) 
GALLOIS, Dominique T. Terras ocupadas? Territórios? Territorialidades? In: RICARDO, Fany (org.). Terras Indigenas e Unidades de Conservação da Natureza: o desafio das sobreposições. São Paulo: Instituto Socioambiental, 2004.

GIACCARIA, Bartolomeu; HEIDE, Adalberto. Xavante Awe Uptabi: Povo Autêntico. São Paulo: Editorial Dom Bosco,1972.

HAESBAERT, R. O mito da desterritorialização: do "fim dos territórios" à multiterritorialidade. Rio de Janeiro: Bertrand Brasil, 2004.

HAVT, Nadja B. Representações do ambiente e territorialidade entre os Zo 'él $P A$. Dissertação de Mestrado, São Paulo: USP, 2001.

. Processos e produtos territoriais: território indígena é terra indígena? In: Revista de estudos em relações interétnicas, v. 3 n. 1, 1999.

LADEIRA, Maria Inês. Espaço geográfico Guarny-Mbya: Significado, constituição e uso. Tese de Doutorado, FFLCH/USP, 2001.

LIMA, Antonio Carlos de Souza. A 'identificação' como categoria histórica. In: OLIVEIRA, João Pacheco (org.). Indigenismo e Territorialização. Rio de Janeiro: Contra Capa Livraria Ltda, p. 171-220, 1998.

Um Grande Cerco de Paz. Poder Tutelar, Indianidade e Formação do Estado no Brasil. Petrópolis: Vozes, 1995.

LINHARES, Alexandre. Da admissibilidade dos títulos da dívida agrária dados em garantia da execução fiscal. Disponível em: https:/jus.com.br/artigos/1348/ da-admissibilidade-dos-titulos-da-divida-agraria-dados-em-garantia-da-execucao-fiscal. 2000. Acesso em: 13 mai. 2020.

LOPES DA SILVA, Aracy. A expressão mítica da vivência histórica: tempo e espaço na construção da identidade Xavante. Anuário Antropológico/82. Fortaleza/Rio de Janeiro: Tempo Brasileiro, 1984.

. Nomes e amigos: da prática Xavante a uma reflexão sobre os Jê. Tese de doutorado, FFLCH-USP, 1980.

. Dois séculos e meio de história Xavante. In: Cunha, Manoela C. (org.). História dos índios no Brasil. São Paulo: Cia das Letras, 1992.

LOPES, Marta M. A resistência do índio ao extermínio: o caso dos Awe-Xavante, 1967-1980, Dissertação de Mestrado em História. Assis/SP: Unesp, 1988.

MAYBURY-LEWIS, David. A sociedade Xavante. Rio de Janeiro: Ed. Francisco Alves, 1984, 1967.

. Conferência: Estruturas e Estratégias. Anuário Antropológico, Rio de Janeiro: Tempo Brasileiro e UnB, v. 86, 1988.

MENEZES, Cláudia Sá Rego Ribeiro de. Missionários e índios em Mato Grosso: os Xavantes da Reserva de São Marcos. Tese de Doutorado São Paulo: USP, 1984.

MINISTÉRIO DA JUSTIÇA; FUNAI. Documentos do GT Parabubure - Processo no 17069/79: "Carta de Apresentação" - Mario Andreazza - Ministro do Interior, 1979.

. Estudo $n^{\circ}$ 012/3a.SC/79 - Reserva Indígena Couto Magalhães,1979.

. Estudo 220/3a. SC/79 - Proposta para a Criação da Reserva Indígena de Parabubure, 1979.

. Documentos anexos ao Processo de Revisão de Limites da T.I. Parabubure, 1983-2003.

OLIVEIRA, João Pacheco. Uma etnologia dos “índios misturados"? Situação colonial, territorialização e fluxos culturais. Mana: Estudos de Antropologia Social, Rio de Janeiro: PPGAS/Museu Nacional/UFRJ, Contra Capa, v. 4, n. 1 , abr. 1998.

. O Nosso Governo: os Ticuna e o Regime Tutelar. São Paulo: Editora Marco Zero, 1988. 
OLIVEIRA, João P. de; ALMEIDA, Alfredo W. B. de. Demarcação e reafirmação étnica: um ensaio sobre a FUNAI. In: OLIVEIRA, João Pacheco (org.). Indigenismo e Territorialização. Rio de Janeiro: Contra Capa Livraria Ltda, Horizontes Antropológicos, Porto Alegre, ano 6, n. 14, nov. 2000.

SAHLINS, M. Ilhas de história. Rio de Janeiro: Zahar Editor, 1987.

SANTILLI, Paulo. Pemongon Pata: território Macuxi, rotas de conflito. São Paulo: Editora Unesp, Rev. Antropol., São Paulo, v. 46, n.1, 2003.

SBARDELLOTTO, Pe. Pedro. Sugestões para criação de reservas para os índios Xavante. In: Chovelon, Pe. Hipólito; Fernandes, Me. Francisco; Sbardellotto, Pe. Pedro. Do primeiro encontro com os Xavante à demarcação de suas reservas. Campo Grande - MS: Missão Salesiana de Mato Grosso, 1996.

STAVENHAGEN, Rodolfo. Clases, colonialismo y aculturación. América Latina: Revista del Centro Latinoamericano de Investigaciones en Ciencias Sociales, VI (4), Río de Janeiro, 1963.

SEEGER, A.; VIVEIROS DE CASTRO, E. Terras e territórios indígenas no Brasil. Revista Encontros com a Civilização Brasileira, Rio de Janeiro: Editora Civilização Brasileira, n. 12, 1979.

VIANNA, Fernando Luiz Brito. Boleiros do Cerrado - índios Xavantes e o futebol. São Paulo: FAPESP/ISA/Annablume, 2008. 